\title{
Distribution and abundance of fish larvae in the northern Ionian Sea (Eastern Mediterranean)
}

\author{
Antonia Granata $\cdot$ Annaluce Cubeta $\cdot$ \\ Roberta Minutoli • Alessandro Bergamasco • \\ Letterio Guglielmo
}

Received: 21 October 2009/Revised: 1 October 2010/Accepted: 5 October 2010/Published online: 26 October 2010

(C) Springer-Verlag and AWI 2010

\begin{abstract}
The purpose of this paper was to study the spatial distribution, abundance and composition of fish larvae in the northern Ionian Sea. Samples were collected to the $600 \mathrm{~m}$ depth with an electronic multinet BIONESS during the "INTERREG Italia-Grecia" oceanographic cruise carried out in March 2000 off the Apulian Italian coast. A total of 46 species of teleost early stages were collected, belonging to 38 genera and 22 families. Over $52 \%$ of the larvae identified were mesopelagic species, almost $27 \%$ were demersal and about $21 \%$ pelagic. A total of 307 myctophids, 69 clupeids and 61 gadid post-larvae dominated the community. Benthosema glaciale (mean $6.1 \mathrm{~mm} \mathrm{SL}$ ) was the most abundant species $(21.6 \%)$, the most frequent in the samples $(28.8 \%)$, and dominant in the whole study area (mean $1.4 \mathrm{ind} / 100 \mathrm{~m}^{3}$ ). Particular attention was given to the horizontal and vertical distribution and abundance of the three dominant post-larval species: Benthosema glaciale, Sprattus sprattus sprattus and Notoscopelus elongatus. The Pearson coefficient $(R=0.734)$ showed a high correlation between total zooplankton and fish larval assemblages in terms of spatial distribution abundance values. Regarding the vertical distribution of fish larvae, Sorensen's index $(S=0.69)$ showed that fish
\end{abstract}

Communicated by Arne Malzahn.

A. Granata - A. Cubeta · R. Minutoli $(\bowtie) \cdot$ L. Guglielmo

Department of Animal Biology and Marine Ecology,

University of Messina, Viale Ferdinando Stagno D'Alcontres 31,

98166 Messina, Italy

e-mail: rminutoli@unime.it

A. Bergamasco

CNR-Istituto per l'Ambiente Marino Costiero,

Sezione di Messina, Spianata S. Raineri 86, 98122 Messina, Italy larvae and total zooplankton abundance peaks co-occurred along the water column.

Keywords Eastern Mediterranean Sea .

Ichthyoplankton · Ecology $\cdot$ Diversity $\cdot$ BIONESS

\section{Introduction}

Larval fish assemblages are temporary components (meroplankton) of the zooplankton community, the structure of which is ultimately dependent upon reproductive cycles within populations of adult fishes. Patterns of larval fish distribution originate from complex spatial and temporal interrelationships that are strongly affected by the seasonality and duration of their meroplanktonic existence (Olivar et al. 1998; Koutrakis et al. 2004; Palomera et al. 2005). Several studies have focused on how biological processes such as high food concentrations, low predator stocks, and certain hydrographic features regulate the distribution and abundance of planktonic organisms, including fish larvae (Sabates et al. 2004; Somarakis et al. 2000, 2006), even if biological-physical interactions are considered to be more important than purely biological forcing mechanisms (Cuttitta et al. 2004; Sabates 2004). It has been shown that coastal environments often constitute favourable habitats for the early life stages of fishes living in different marine ecosystems (McGowen 1993), representing nursery areas for species exhibiting distinct spawning habits (e.g. demersal, pelagic or beach spawning) (McGowen 1993).

Late winter-early spring usually represents a period of low density values (Sabatés and Masò 1992) and high species richness (Palomera and Olivar 1996) for the larvae of most species in the Mediterranean Sea. Early life stages 
of the species of lanternfish Benthosema glaciale often dominate the early spring larval fish community. B. glaciale is a high-oceanic, mesopelagic fish that is endemic in the Mediterranean and Atlantic Seas (Whitehead et al. 1984) and which does not present a well-defined spawning season (Gjøsaeter and Kawaguchi 1980). Its distribution and abundance play an important role in the cycling of energy in the marine food web, since the species is preyed upon by several commercial fish species, including hake and horse mackerel (Acevedo and Fives 2001).

In the Mediterranean, information on larval fish ecology in the northern Ionian Sea is lacking (Giovanardi et al. 1989; Potoschi et al. 1994; D'Onghia et al. 2003; D'Onghia et al. 2004a, b; Mytilineou et al. 2005). The northern Ionian area is characterized by a sea bottom that slopes gradually, down from the Italian coast to the continental shelf until the $1,000 \mathrm{~m}$ depth, pattern so present also out off the coast between Gallipoli and Otranto. Convective processes in this area generate cold, dense and oxygenated deep waters that outflow into the Ionian Sea and feed deep layers of the Eastern Mediterranean (Gacic et al. 1999). This is due to an alongshore current of variable strength, resulting from combined effects of wind and buoyancy forcing, directed southwards along the western coast of the Adriatic and into the Ionian Sea (Giordani et al. 2002).

The Strait of Otranto is characterized by the presence of four main water masses (Gacic et al. 1996; Manca and Scarazzato 2001): Adriatic Surface Water (ASW), with minimum temperatures of about $11^{\circ} \mathrm{C}$ in winter, flowing out of the Adriatic Sea along the western side of the Strait; Ionian Surface Water (ISW), that is saltier $(S>38.25)$ and warmer $\left(T>15^{\circ} \mathrm{C}\right)$ than the ASW, flowing into the Adriatic along the eastern side; Levantine Intermediate Water (LIW), defined by a core of $S>38,75$ in the 200- to 700$\mathrm{m}$ layer; Adriatic Deep Water (ADW, $\theta<13.3^{\circ} \mathrm{C}$; $S<38.70$ ) that flows out into the Ionian Sea and follows the 900-m isobath in the Gulf of Taranto and along the Calabrian coast (Bignami et al. 1990) (see Fig. 1).

The aim of this paper was to study the distribution, abundance and composition of the larval fish community in the northern Ionian Sea and its relationship with total zooplankton abundance and water mass structure. To achieve this objective, we employed an electronic zooplankton multi-net that simultaneously sampled 10-12 layers along the water column and measured chemical and physical parameters that characterized the water column. The distribution of the more abundant post-larval species having an ecological importance in this region Benthosema glaciale, Sprattus sprattus sprattus and Notoscopelus elongatus (Stergiou and Karpouzi 2002; Cuttitta et al. 2004; D’Onghia et al. 2004a, b) were analyzed.

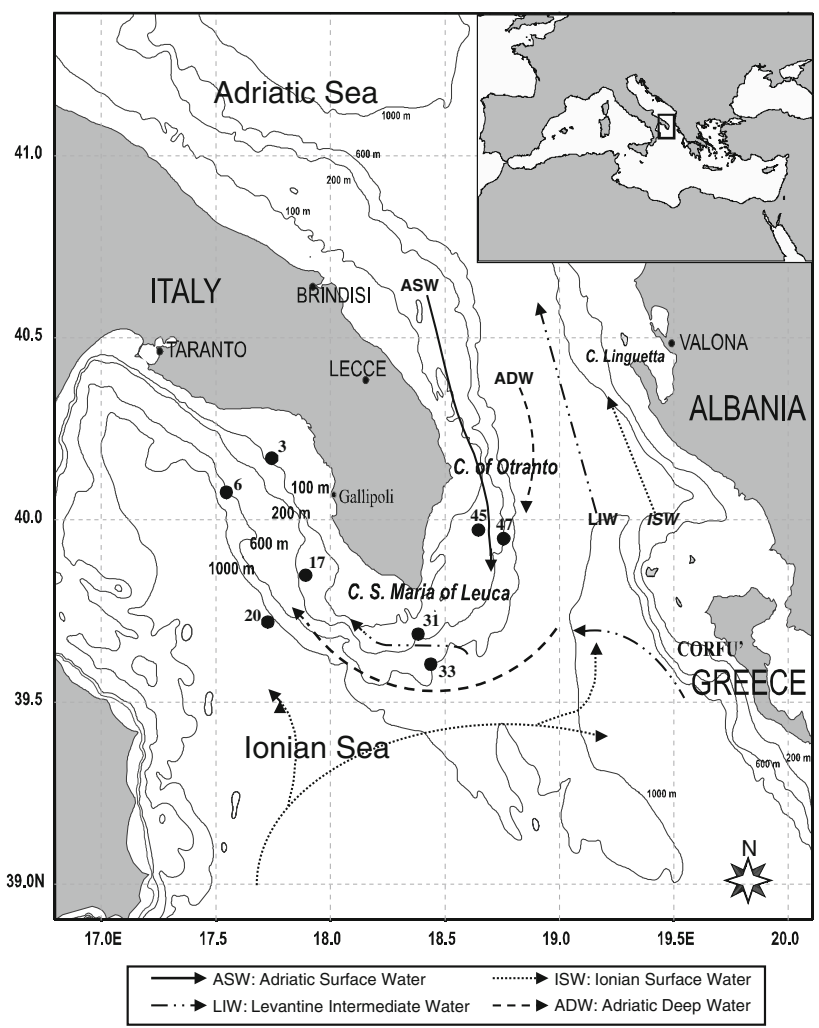

Fig. 1 Study area and stations sampled with the BIONESS during the INTERREG Italia-Grecia cruise (11-20 March 2000)

\section{Materials and methods}

Sampling and laboratory procedure

The study area was the northern Ionian Sea in the Eastern Mediterranean, between the Italian Apulian coast and Greece. During the oceanographic cruise "INTERREG Italia-Grecia", carried out from the 11th to the 20th of March 2000, zooplankton samples were taken at 8 stations $(3,6,17,20,31,33,45,47)$ off the Apulian coast, to the maximum depth located on four inshore-offshore transects (Fig. 1), in order to investigate the vertical and horizontal distribution of fish larvae along different isobaths. Employing cluster techniques on samples averaged across stations (Fig. 2), we distinguished four significantly different groups at 50\% similarity level: A, inshore/coastal stations (3, 17 and 45 ; bathymetry range 110-142 m); $\mathrm{B}$, shelf/slope stations ( 31 and 47 ; bathymetry range 200-320 m); C, offshore station (33; bottom depth $620 \mathrm{~m}$ ); $\mathrm{D}$, pelagic stations $(20 ; 1,100 \mathrm{~m}$ bottom depth). Station 6 (bottom depth $630 \mathrm{~m}$ ), even if located on the same isobath as station 33, showed different features and therefore was not grouped.

Primer 5 (Clark and Gorley 2001) was used to investigate horizontal and vertical similarities/dissimilarities of 
Fig. 2 Bray-Curtis cluster analysis (Group Average) of larval fish abundance along the Salento Peninsula (northern Ionian Sea). For each station, abundance data for each species were pooled along the column, standardized and square-root transformed

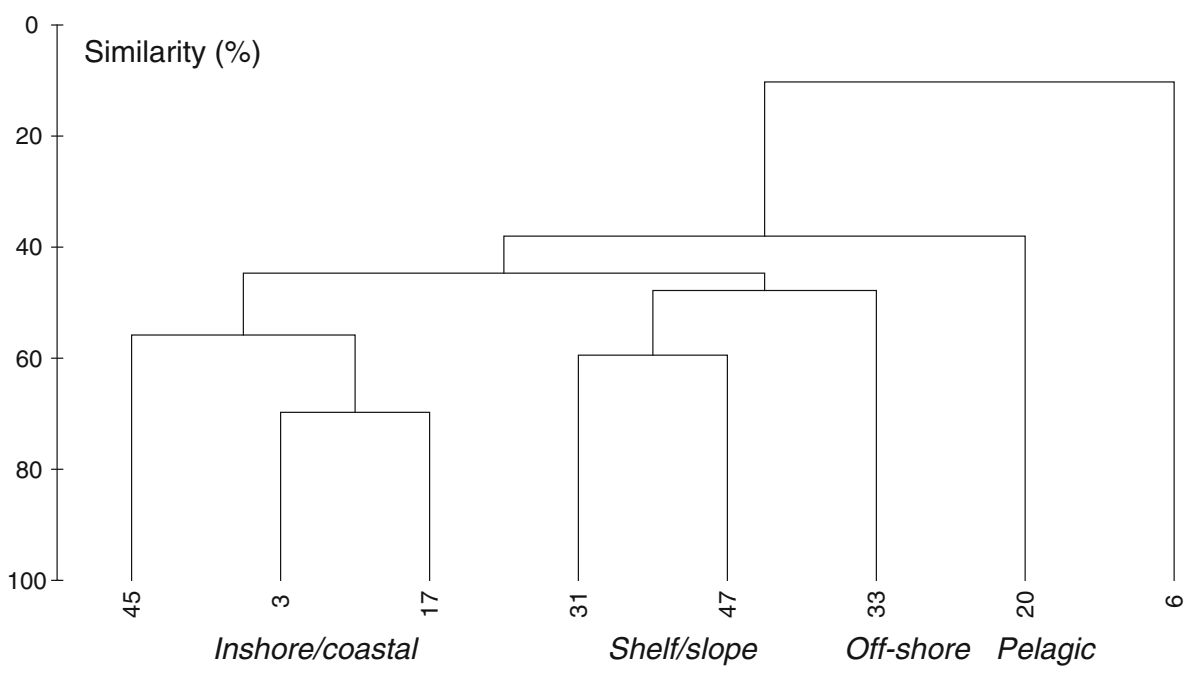

fish larval assemblages (Bray-Curtis cluster analysis, similarity percentages). Abundance data were normalized to the total abundance and square-root transformed.

Zooplankton samples were collected simultaneously along the water column with the electronic multinet EZNET BIONESS (Bedford Institute of Oceanography Net and Environmental Sampling System) (Sameoto et al. 1980) by our operative unit "CoNISMa-Messina, Zooplankton and Micronekton" involved in a project to study the south Adriatic and north Ionian Seas. The BIONESS is a multiple-opening and closing-net sampler equipped with 10 nets with a square mouth opening of $0.25 \mathrm{~m}^{2}$ each and a mesh size of $230 \mu \mathrm{m}$. Flow through the nets was monitored with external and internal TSK flowmeters. The EZ-NET BIONESS continuously measured temperature, salinity and depth during tows by means of an Applied Microsystems digital CTD. The EZ-NET BIONESS was towed at a speed of $1-1.5 \mathrm{~m} / \mathrm{s}$ as it was slowly lowered along an oblique path to the desired depth. Each haul lasted from 36 to $120 \mathrm{~min}$, depending on the interval investigated. During each tow, the first net was used to downward collect the entire water column to the maximum depth sampled. Sampling upwards, the nets were opened and closed on command, for $20-\mathrm{m}$ intervals in the hauls programmed in the upper $100 \mathrm{~m}$, and for 100-m intervals below this zone to the maximum depth sampled. Sampling details are shown in Table 1.

A total of 52 samples were taken. These were preserved on board with $5 \%$ buffered formaldehyde and seawater solution. Qualitative and quantitative analyses were carried out on the 52 preserved samples. To determine total zooplankton abundances, subsamples of $1 / 10$ to $1 / 25$ of $1-1$ sample were taken and observed under a stereomicroscope (Leica Wild M10). The samples were observed entirely for the identification of rare species, and to count, diagnose and sort bigger specimens, like micronekton including fish larvae (animals $>1 \mathrm{~cm}$ ). All organisms of each taxon were counted and classified at higher taxonomic levels, while species-level identifications were carried out only for the main groups, including copepods, cladocerans, euphausiids and chaetognaths. All data are reported as total abundance in 11 , divided by the volume of seawater filtered during net tows, and expressed as $\mathrm{N} / \mathrm{m}^{3}$.

Each larval fish specimen was identified to the lowest taxonomic level possible and measured at standard length (SL) to the nearest millimetre to obtain the mean, minimum-maximum range of SL and length-frequency distribution for the dominant species. Shrinkage due to formaldehyde solution (about 10\%) was not considered. The nomenclature and systematic order of the species were reported according to Hureau and Monod (1978) and Whitehead et al. (1984-1986), updated to the web site www.fishbase.org. Abundance values were expressed as ind $/ 100 \mathrm{~m}^{3}$.

After micronekton (all the animals $>1 \mathrm{~cm}$, including fish larvae) were removed, a 250-ml subsample from each 1-1 sample was collected for the estimation of total zooplankton biomass using a Folsom Splitter. Samples were wet weighed according to the method of Tranter (1962) on an analytic balance (Mettler Toledo). After drying for $24 \mathrm{~h}$ at $60^{\circ} \mathrm{C}$ in an oven (BICASA Sterox 106), stabilized dry weight for all subsamples were measured with an analytic balance. Biomass values (wet and dry weights) were expressed as $\mathrm{mg} / \mathrm{m}^{3}$ of filtered seawater.

A frequency index and a category of abundance have been assigned to the species following Dajoz (1971). The frequency index was estimated as the percentage ratio between number of samples in which the species was found and the total number of samples collected $\left(i_{\mathrm{f}}=n_{\mathrm{i}} / N_{\mathrm{T}}\right)$. The use of a combination of a frequency index and abundance 
Table 1 Sampling data, total zooplankton density $\left(\mathrm{N} / \mathrm{m}^{3}\right)$ and related biomass values of "INTERREG Italia-Grecia" oceanographic cruise (11-20 March 2000)

\begin{tabular}{|c|c|c|c|c|c|c|c|c|c|c|}
\hline \multirow[t]{2}{*}{ Station } & \multirow[t]{2}{*}{ Date } & \multirow{2}{*}{$\begin{array}{l}\text { Time (hours) } \\
\text { Start-end }\end{array}$} & \multicolumn{2}{|l|}{ Co-ordinates } & \multirow{2}{*}{$\begin{array}{l}\text { Bottom } \\
\text { depth } \\
(\mathrm{m})\end{array}$} & \multirow{2}{*}{$\begin{array}{l}\text { Sampling } \\
\text { layers } \\
(\mathrm{m})\end{array}$} & \multirow{2}{*}{$\begin{array}{l}\text { Filtered } \\
\text { volume } \\
\left(\mathrm{m}^{3}\right)\end{array}$} & \multirow{2}{*}{$\begin{array}{l}\text { Density } \\
\left(\mathrm{N} / \mathrm{m}^{3}\right)\end{array}$} & \multirow{2}{*}{$\begin{array}{l}\text { Wet } \\
\text { weight } \\
\left(\mathrm{mg} / \mathrm{m}^{3}\right)\end{array}$} & \multirow{2}{*}{$\begin{array}{l}\text { Dry } \\
\text { weight } \\
\left(\mathrm{mg} / \mathrm{m}^{3}\right)\end{array}$} \\
\hline & & & Start & End & & & & & & \\
\hline \multirow[t]{5}{*}{3} & \multirow[t]{5}{*}{$3 / 11 / 2000$} & \multirow[t]{5}{*}{ 00:38-01:31 p.m. } & Lat. $40^{\circ} 09.20$ & Lat. $40^{\circ} 08.74$ & \multirow[t]{5}{*}{115} & $100-80$ & 114.68 & 68.86 & 9.67 & 1.38 \\
\hline & & & \multirow[t]{4}{*}{ Lon. $17^{\circ} 43.20$} & \multirow[t]{4}{*}{ Lon. $17^{\circ} 41.40$} & & $80-60$ & 153.18 & 45.61 & 6.28 & 0.90 \\
\hline & & & & & & $60-40$ & 185.63 & 83.96 & 11.55 & 1.65 \\
\hline & & & & & & $40-20$ & 146.30 & 252.83 & 35.38 & 5.05 \\
\hline & & & & & & $20-0$ & 192.50 & 435.14 & 63.32 & 9.00 \\
\hline \multirow[t]{9}{*}{6} & \multirow[t]{9}{*}{$3 / 11 / 2000$} & \multirow[t]{9}{*}{ 05:12-06:47 p.m. } & Lat. $40^{\circ} 04.14$ & Lat. $40^{\circ} 01.34$ & \multirow[t]{9}{*}{630} & $500-400$ & 214.50 & 0.07 & $*$ & $*$ \\
\hline & & & \multirow[t]{8}{*}{ Lon. $17^{\circ} 32.86$} & Lon. $17^{\circ} 31.80$ & & $400-300$ & 201.85 & 0.22 & $*$ & $*$ \\
\hline & & & & & & $300-200$ & 174.08 & 0.27 & $*$ & $*$ \\
\hline & & & & & & $200-100$ & 148.78 & 8.07 & 1.19 & 0.17 \\
\hline & & & & & & $100-80$ & 132.55 & 1.46 & 0.21 & 0.03 \\
\hline & & & & & & $80-60$ & 135.58 & 0.43 & $*$ & $*$ \\
\hline & & & & & & $60-40$ & 101.75 & 0.28 & $*$ & $*$ \\
\hline & & & & & & $40-20$ & 103.95 & 1.97 & 0.29 & 0.04 \\
\hline & & & & & & $20-0$ & 125.40 & 140.47 & 18.87 & 2.70 \\
\hline 17 & $3 / 13 / 2000$ & 05:30-06:42 p.m. & Lat. $39^{\circ} 50.63$ & Lat. $39^{\circ} 48.77$ & 142 & $100-80$ & 162.53 & 40.80 & 1.45 & 0.21 \\
\hline & & & Lon. $17^{\circ} 52.97$ & Lon. $17^{\circ} 50.64$ & & $80-60$ & 164.73 & 40.97 & 3.41 & 0.49 \\
\hline & & & & & & $60-40$ & 162.80 & 62.19 & 8.36 & 1.19 \\
\hline & & & & & & $40-20$ & 167.75 & 187.33 & 21.16 & 3.02 \\
\hline & & & & & & $20-0$ & 246.95 & 160.98 & 19.88 & 2.84 \\
\hline 20 & $3 / 13 / 2000$ & 9:43-11:43 p.m. & Lat. $39^{\circ} 42.81$ & Lat. $39^{\circ} 43.74$ & 1,100 & $600-400$ & 239.80 & 0.33 & 0.01 & 0.00 \\
\hline & & & Lon. $17^{\circ} 43.08$ & Lon. $17^{\circ} 48.90$ & & $400-300$ & 169.13 & 1.49 & 0.01 & 0.00 \\
\hline & & & & & & $300-200$ & 197.18 & 0.28 & 0.01 & 0.00 \\
\hline & & & & & & $200-100$ & 180.13 & 0.91 & 0.04 & 0.01 \\
\hline & & & & & & $100-80$ & 166.38 & 11.24 & 1.15 & 0.16 \\
\hline & & & & & & $80-60$ & 170.23 & 1.20 & 0.08 & 0.01 \\
\hline & & & & & & $60-40$ & 169.40 & 1.78 & 0.13 & 0.02 \\
\hline & & & & & & $40-20$ & 166.38 & 109.48 & 14.58 & 2.08 \\
\hline & & & & & & $20-0$ & 235.13 & 288.54 & 34.22 & 4.89 \\
\hline 31 & $3 / 14 / 2000$ & 11:38 a.m.-00:41 p.m. & Lat. $39^{\circ} 40.19$ & Lat. $39^{\circ} 38.00$ & 200 & $100-80$ & 183.70 & 22.65 & 2.74 & 0.39 \\
\hline & & & Lon. $18^{\circ} 24.27$ & Lon. $18^{\circ} 25.04$ & & $80-60$ & 167.75 & 77.97 & 9.35 & 1.34 \\
\hline & & & & & & $60-0$ & 598.95 & 93.96 & 11.85 & 1.69 \\
\hline 33 & $3 / 14 / 2000$ & 02:27-04:03 p.m. & Lat. $39^{\circ} 36.35$ & Lat. $39^{\circ} 37.40$ & 620 & $500-400$ & 202.95 & 0.14 & 0.01 & 0.00 \\
\hline & & & Lon. $18^{\circ} 27.26$ & Lon. $18^{\circ} 34.14$ & & $400-300$ & 170.50 & 0.18 & 0.01 & 0.00 \\
\hline & & & & & & $300-200$ & 194.98 & 0.24 & 0.01 & 0.00 \\
\hline & & & & & & $200-100$ & 190.30 & 1.68 & 0.22 & 0.03 \\
\hline & & & & & & $100-80$ & 168.58 & 15.66 & 1.75 & 0.25 \\
\hline & & & & & & $80-60$ & 166.38 & 0.78 & 0.11 & 0.02 \\
\hline & & & & & & $40-20$ & 166.10 & 46.24 & 4.56 & 0.65 \\
\hline & & & & & & $20-0$ & 216.43 & 211.07 & 20.06 & 2.87 \\
\hline 45 & $3 / 20 / 2000$ & 02:26-03:26 p.m. & Lat. $39^{\circ} 58.28$ & Lat. $40^{\circ} 00.58$ & 110 & $100-80$ & 171.05 & 43.03 & 4.50 & 0.64 \\
\hline & & & Lon. $18^{\circ} 38.44$ & Lon. $18^{\circ} 39.24$ & & $80-60$ & 176.55 & 73.00 & 8.04 & 1.15 \\
\hline & & & & & & $60-40$ & 184.53 & 113.91 & 12.82 & 1.83 \\
\hline & & & & & & $40-20$ & 179.03 & 214.89 & 23.13 & 3.30 \\
\hline & & & & & & $20-0$ & 225.78 & 147.82 & 13.10 & 1.87 \\
\hline
\end{tabular}


Table 1 continued

\begin{tabular}{|c|c|c|c|c|c|c|c|c|c|c|}
\hline \multirow[t]{2}{*}{ Station } & \multirow[t]{2}{*}{ Date } & \multirow{2}{*}{$\begin{array}{l}\text { Time (hours) } \\
\text { Start-end }\end{array}$} & \multicolumn{2}{|l|}{ Co-ordinates } & \multirow{2}{*}{$\begin{array}{l}\text { Bottom } \\
\text { depth } \\
(\mathrm{m})\end{array}$} & \multirow{2}{*}{$\begin{array}{l}\text { Sampling } \\
\text { layers } \\
\text { (m) }\end{array}$} & \multirow{2}{*}{$\begin{array}{l}\text { Filtered } \\
\text { volume } \\
\left(\mathrm{m}^{3}\right)\end{array}$} & \multirow{2}{*}{$\begin{array}{l}\text { Density } \\
\left(\mathrm{N} / \mathrm{m}^{3}\right)\end{array}$} & \multirow{2}{*}{$\begin{array}{l}\text { Wet } \\
\text { weight } \\
\left(\mathrm{mg} / \mathrm{m}^{3}\right)\end{array}$} & \multirow{2}{*}{$\begin{array}{l}\text { Dry } \\
\text { weight } \\
\left(\mathrm{mg} / \mathrm{m}^{3}\right)\end{array}$} \\
\hline & & & Start & End & & & & & & \\
\hline \multirow[t]{7}{*}{47} & \multirow[t]{7}{*}{$3 / 20 / 2000$} & \multirow[t]{7}{*}{ 05:10-06:41 p.m. } & Lat. $39^{\circ} 56.41$ & Lat. $40^{\circ} 00.75$ & \multirow[t]{7}{*}{320} & $300-200$ & 214.23 & 0.72 & $*$ & $*$ \\
\hline & & & \multirow[t]{6}{*}{ Lon. $18^{\circ} 45.18$} & \multirow[t]{6}{*}{ Lon. $18^{\circ} 44.40$} & & $200-100$ & 198.28 & 3.63 & 0.15 & 0.02 \\
\hline & & & & & & $100-80$ & 166.38 & 1.02 & 0.14 & 0.02 \\
\hline & & & & & & $80-60$ & 167.20 & 26.32 & 2.55 & 0.36 \\
\hline & & & & & & $60-40$ & 171.05 & 20.58 & 1.73 & 0.25 \\
\hline & & & & & & $40-20$ & 166.93 & 3.92 & 0.35 & 0.05 \\
\hline & & & & & & $20-0$ & 226.33 & 118.77 & 10.04 & 1.43 \\
\hline
\end{tabular}

In the samples signed with $*$, it was not possible to carry out the biomass analysis for the scarce density

is important because certain species may be caught several times but with few specimens or they may be collected few times but with a large number of specimens; both estimates depend on the frequency and abundance of the species in the study area relative to the trawl net employed (Matarrese et al. 1996).

The horizontal distribution of total larval fish assemblages is reported as the total number of individuals for all cubic metres filtered and expressed as number of individuals per $100 \mathrm{~m}^{3}$ of filtered sea water $\left(\mathrm{N} / 100 \mathrm{~m}^{3}\right)$. The abundance of each species at the groups of A, B, C and D stations are shown as mean abundances.

The vertical distribution of fish larvae in the water column is reported in relation to temperature and salinity values for all stations. The mean abundance of each species at the groups of A, B, C and D stations was calculated for four bathymetric strata $(0-40 \mathrm{~m}, 40-60 \mathrm{~m}, 60-100 \mathrm{~m}$ and $100-600 \mathrm{~m}$ ) along the water column in the whole study area.

Correlation in terms of horizontal abundance between total zooplankton and fish larvae in the eight sampled stations was statistically tested applying the Pearson correlation coefficient using a mean value among all the sampling layers for any station. For the correlation in terms of vertical distribution along the water column, values of abundance were transformed in binary code, giving a statistically significant co-occurrence of abundance peaks between total zooplankton and fish larvae only when the vertical distributions of the two groups in the same layer overlapped. We used binary data to calculate the Sorensen coefficient (Sorensen 1948; Legendre and Legendre 1998).

\section{Results}

Environmental conditions

The study was carried out in a typical late-winter-earlyspring situation with a generally well-mixed water column, characterized by temperatures around $14^{\circ} \mathrm{C}$ and salinity above 38.4 (CTD profiles shown in Fig. 3). The presence of the different water masses, as well as their spatial distribution, was investigated by analyzing the potential temperature $(\theta)$ versus salinity diagrams in the study area (Fig. 4) during the cruise. The $\theta-\mathrm{S}$ relationship clearly indicated the dominance of Ionian Surface Water in the upper layer $\left(\theta \cong 14.14^{\circ} \mathrm{C} ; S>38.2\right)$, with salinities always exceeding 38.35. In the intermediate layer of stations 33 and 20 (depth $>200$ ), the presence of a saltier water mass $(S>38.75)$ was assigned to levantine waters (LIW). A surface cooling was evident only at the shallow coastal station (station 3), presumably due to winds and coastal inputs. There was no evidence of the presence of waters of Adriatic origin in the area.

\section{Zooplankton}

Mean zooplankton abundance, including fish larvae, combined and averaged across stations and depth strata, was $62.46 \pm$ $89.52 \mathrm{ind} / \mathrm{m}^{3}$ for the entire investigated area. The community was constituted mainly by copepods $\left(49.96 \pm 80.62 \mathrm{ind} / \mathrm{m}^{3}\right)$ and appendicularians $\left(3.39 \pm 7.97 \mathrm{ind} / \mathrm{m}^{3}\right)$, which constituted 79.97 and $5.43 \%$ of the entire community, respectively. Values for zooplankton total abundance (ind $/ \mathrm{m}^{3}$ ) and biomass, expressed as wet $\left(\mathrm{mg} / \mathrm{m}^{3}\right)$ and dry $\left(\mathrm{mg} / \mathrm{m}^{3}\right)$ weights, are shown in Table 1. The horizontal distribution of total zooplankton abundance showed a decreasing gradient towards the offshore stations, with a mean density of $69.54 \mathrm{ind} / \mathrm{m}^{3}$ for inshore and $52.18 \mathrm{ind} / \mathrm{m}^{3}$ for offshore stations. Highest abundances were recorded at station $3\left(886,41 \mathrm{ind} / \mathrm{m}^{3}\right)$, whereas the lowest at station $6\left(153,24 \mathrm{ind} / \mathrm{m}^{3}\right)$. The lowest value was recorded $(0,07$ $\left.\mathrm{ind} / \mathrm{m}^{3}\right)$ in the 500-to 400 - $\mathrm{m}$ layer at station 6 , while the highest value $\left(435,14 \mathrm{ind} / \mathrm{m}^{3}\right)$ in the 20 - to 0 -m layer at station 3 . The vertical distribution showed a clear decreasing gradient from the surface to the maximum sampled depth for all stations, with highest biomass in the 0- to 40-m layer. Another peak in both biomass and abundance occurred in the 80- to 100-m layer at station 20 . 
Fig. 3 Vertical distribution of fish larvae $\left(\mathrm{N} / 100 \mathrm{~m}^{3}\right.$, grey bars) and vertical temperature $\left({ }^{\circ} \mathrm{C}\right)$ and salinity (psu) profiles for all sampled stations ( $m$ morning, $a$ afternoon, $n$ night) (a) inshore/coastal stations
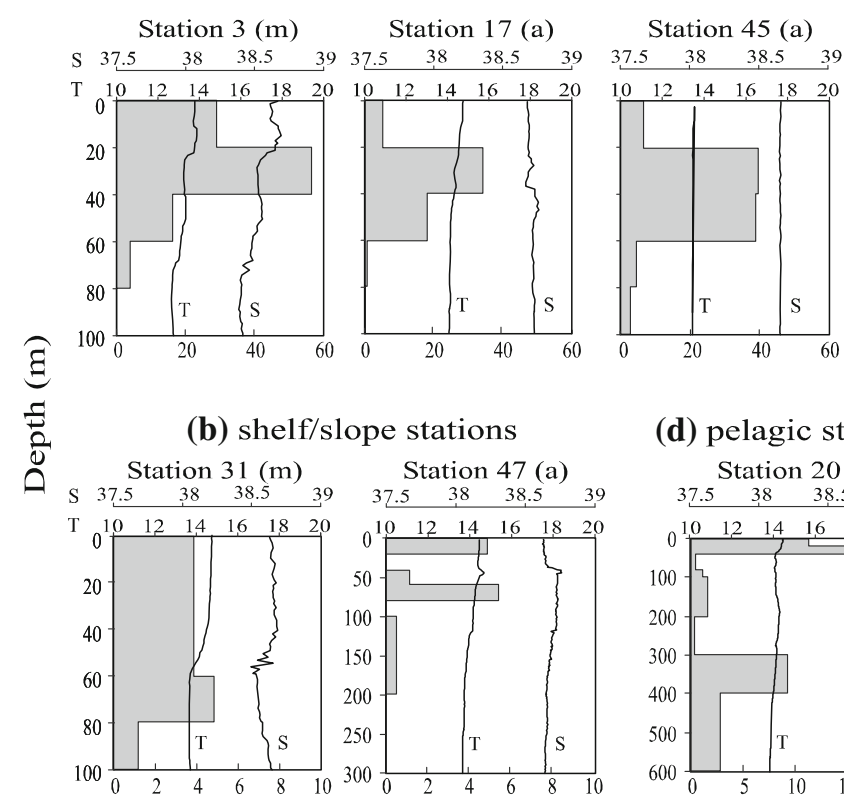

(c) offshore station

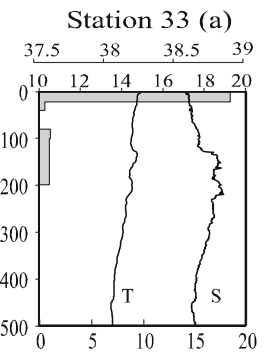

(d) pelagic station
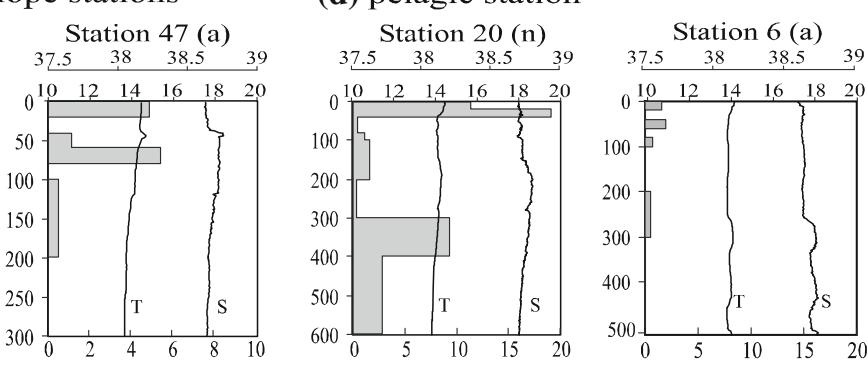

Ind $100 \mathrm{~m}^{-3}$

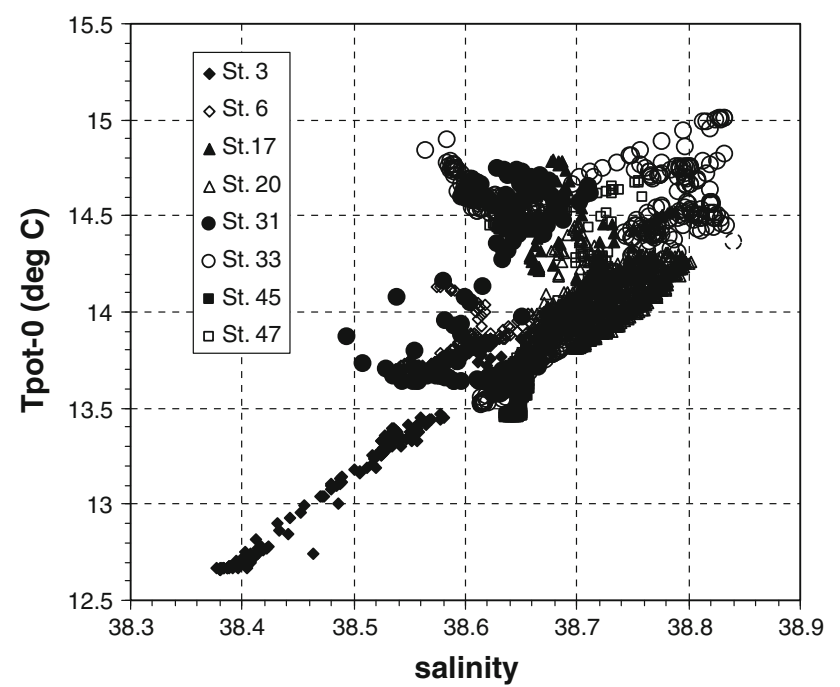

Fig. $4 \theta-S$ relationship for the CTD profiles along the Salento Peninsula

Fish larvae

\section{Composition}

The larval fish community consisted in a total of 645 individuals represented mainly by post-larvae, with few metamorphosing stages and juvenile fishes. A total of 46 species, belonging to 38 genera and 22 families, were collected (Table 2). Over $52 \%$ of the larvae identified were mesopelagic fish species, almost $27 \%$ were demersal and about $21 \%$ were pelagic species. A total of 304 myctophids, 80 clupeids and 79 gadid post-larvae dominated the community (over $70 \%$ of the total community).

Early stages of fishes, belonging to very different habitats as adults, co-occurred: coastal epipelagic species, e.g., clupeid Sprattus sprattus sprattus, sparid Boops boops, carangid Trachurus trachurus; meso- and bathypelagic species, e.g., gonostomatid $C$. braueri, mictophids B. glaciale, Notoscopelus elongatus, Lampanyctus crocodilus, L. pusillus, Myctophum punctatum, paralepidid Lestidiops jayakari pseudosphyraenoides, stomiatid Stomias boa boa; shelf-dwelling and demersal species, e.g., bothid Arnoglossus laterna, ammodytid, Gymnammodytes cicerellus, some callionimids and congrid Gnathophis mystax; benthopelagic species, e.g., carangid Trachurus picturatus.

Benthosema glaciale was the most abundant and frequent species in the samples, being dominant in the whole study area. Other representative myctophids such as Notoscopelus elongatus and Lampanyctus crocodilus had low abundances in the study area but were caught with a high frequency index in the samples. Clupeids (12.5\% of all fish larvae present in $21 \%$ of the samples) were represented by Sprattus sprattus sprattus that showed higher density values in the whole study area during the sampling period than the other clupeid species Sardina pilchardus (70 and 5 specimens, respectively). Gadidae was the third numerically important family of total fish larvae with 5 identified species occurring in $31 \%$ of the samples. Callionymidae $(7.5 \%)$ and Gonostomatidae $(5.4 \%)$ followed, in decreasing order. Stomiatid Stomias boa boa, Carangids Trachurus picturatus and T. trachurus, ammodytid Gymnammodytes cicerelus, sparids Boops boops and 
Table 2 Species composition of ichthyoplankton community

\begin{tabular}{|c|c|c|c|c|c|c|c|}
\hline Species/family & $N$ & $\begin{array}{l}\text { Relative } \\
\text { abundance (\%) }\end{array}$ & $\begin{array}{l}\text { Frequency } \\
\text { index }(\%)\end{array}$ & $\begin{array}{l}\text { Mean abundance } \\
\left(\mathrm{N} / 100 \mathrm{~m}^{3}\right)\end{array}$ & $\mathrm{SL}(\mathrm{mm})$ & $X(\mathrm{~mm})$ & $(+\mathrm{SD})$ \\
\hline \multicolumn{8}{|l|}{ Clupeidae } \\
\hline Sprattus sprattus sprattus & 70 & 10.9 & 11.5 & 0.73 & $6-22$ & 10.6 & 2.7 \\
\hline Sardina pilchardus & 5 & 0.8 & 3.8 & 0.05 & $8-14$ & 11.2 & 0.5 \\
\hline Clupeidae sp. & 5 & 0.8 & 5.8 & 0.05 & - & - & - \\
\hline \multicolumn{8}{|l|}{ Gonostomatidae } \\
\hline Cyclothone braueri & 10 & 1.6 & 9.6 & 0.10 & $3-8$ & 4.0 & 0.5 \\
\hline Cyclothone microdon & 1 & 0.2 & 1.9 & 0.01 & 8 & 8.0 & - \\
\hline Cyclothone spp. & 23 & 3.6 & 5.8 & 0.24 & - & - & - \\
\hline \multicolumn{8}{|l|}{ Sternoptychidae } \\
\hline Argyropelecus hemigymnus & 2 & 0.3 & 3.8 & 0.02 & $18-25$ & 21.5 & 0.5 \\
\hline Photychthidae & & & & 0.00 & & & \\
\hline Ichthyococcus ovatus & 6 & 0.9 & 9.6 & 0.06 & $16-25$ & 19.2 & 0.7 \\
\hline Vinciguerria poweriae & 1 & 0.2 & 1.9 & 0.01 & 18 & 18.0 & - \\
\hline \multicolumn{8}{|l|}{ Stomiatidae } \\
\hline Stomias boa boa & 19 & 2.9 & 19.2 & 0.20 & $4-43$ & 18.9 & 5.1 \\
\hline \multicolumn{8}{|l|}{ Myctophidae } \\
\hline Benthosema glaciale & 151 & 23.4 & 30.8 & 1.58 & $3-13$ & 6.1 & 2.2 \\
\hline Ceratoscopelus maderensis & 1 & 0.2 & 1.9 & 0.01 & 15 & - & - \\
\hline Hygophum benoiti & 7 & 1.1 & 9.6 & 0.07 & $10-15$ & 11.9 & 0.5 \\
\hline Hygophum hygomii & 10 & 1.6 & 13.5 & 0.10 & $4-11$ & 6.3 & 0.8 \\
\hline Lampanyctus crocodilus & 32 & 5.0 & 19.2 & 0.33 & $4-17$ & 5.6 & 1.4 \\
\hline Lampanyctus pusillus & 17 & 2.6 & 21.2 & 0.18 & $3-8$ & 5.0 & 0.6 \\
\hline Lobianchia dofleini & 3 & 0.5 & 5.8 & 0.03 & $5-16$ & 8.8 & 0.9 \\
\hline Myctophum punctatum & 28 & 4.3 & 17.3 & 0.29 & $3-9$ & 4.6 & 0.7 \\
\hline Notoscopelus bolini & 8 & 1.2 & 13.5 & 0.08 & $3-13$ & 8.3 & 1.1 \\
\hline Notoscopelus elongatus & 33 & 5.1 & 19.2 & 0.34 & $3-16$ & 5.4 & 1.5 \\
\hline Symbolophorus veranyi & 1 & 0.2 & 1.9 & 0.01 & 16 & - & - \\
\hline Myctophidae spp. & 13 & 2.0 & 1.9 & 0.14 & - & - & - \\
\hline \multicolumn{8}{|l|}{ Paralepididae } \\
\hline Lestidiops jayakari jayakari & 5 & 0.8 & 5.8 & 0.05 & $4-14$ & 5.0 & 0.2 \\
\hline Arctozenus risso & 4 & 0.6 & 7.7 & 0.04 & $5-14$ & 10.8 & 0.7 \\
\hline Paralepis sp. & 1 & 0.2 & 1.9 & 0.01 & Damag. & - & - \\
\hline \multicolumn{8}{|l|}{ Congridae } \\
\hline Gnathophis mystax & 2 & 0.3 & 3.8 & 0.02 & $70-103$ & 86.5 & 1.7 \\
\hline Apodes sp. & 1 & 0.2 & 1.9 & 0.01 & - & - & - \\
\hline \multicolumn{8}{|l|}{ Macroramphosidae } \\
\hline Macroramphosus scolopax & 3 & 0.5 & 5.8 & 0.03 & $2-6$ & 3.7 & 0.3 \\
\hline \multicolumn{8}{|l|}{ Gadidae } \\
\hline Gaidropsarus biscayensis & 50 & 7.8 & 17.3 & 0.52 & $1-4$ & 2.2 & 0.3 \\
\hline Gadiculus argenteus thori & 2 & 0.3 & 3.8 & 0.02 & $4-5$ & 4.5 & 0.1 \\
\hline Gaidropsarus vulgaris & 1 & 0.2 & 1.9 & 0.01 & 13 & - & - \\
\hline Phycis phycis & 5 & 0.8 & 5.8 & 0.05 & $2-5$ & 4.0 & 0.2 \\
\hline Gadus spp. & 3 & 0.5 & 1.9 & 0.03 & - & - & - \\
\hline Gadidae spp. & 18 & 2.8 & 15.4 & 0.19 & - & - & - \\
\hline \multicolumn{8}{|l|}{ Merluccidae } \\
\hline Merluccius merluccius & 1 & 0.2 & 1.9 & 0.01 & 4 & - & - \\
\hline \multicolumn{8}{|l|}{ Caproidae } \\
\hline Capros aper & 5 & 0.8 & 9.6 & 0.05 & 2 & 2.0 & - \\
\hline
\end{tabular}


Table 2 continued

\begin{tabular}{|c|c|c|c|c|c|c|c|}
\hline Species/family & $N$ & $\begin{array}{l}\text { Relative } \\
\text { abundance (\%) }\end{array}$ & $\begin{array}{l}\text { Frequency } \\
\text { index }(\%)\end{array}$ & $\begin{array}{l}\text { Mean abundance } \\
\left(\mathrm{N} / 100 \mathrm{~m}^{3}\right)\end{array}$ & $\mathrm{SL}(\mathrm{mm})$ & $X(\mathrm{~mm})$ & $(+\mathrm{SD})$ \\
\hline \multicolumn{8}{|l|}{ Carangidae } \\
\hline Trachurus picturatus & 14 & 2.2 & 7.7 & 0.15 & $3-4$ & 3.2 & 0.2 \\
\hline Trachurus trachurus & 3 & 0.5 & 3.8 & 0.03 & $2-3$ & 2.5 & 0.1 \\
\hline \multicolumn{8}{|l|}{ Sparidae } \\
\hline Boops boops & 11 & 1.7 & 7.7 & 0.11 & $2-5$ & 3.2 & 0.4 \\
\hline Diplodus sargus sargus & 2 & 0.3 & 3.8 & 0.02 & 3 & - & - \\
\hline \multicolumn{8}{|l|}{ Ammodytidae } \\
\hline Gymnammodytes cicerellus & 16 & 2.5 & 7.7 & 0.17 & $6-13$ & 9.1 & 0.8 \\
\hline \multicolumn{8}{|l|}{ Uranoscopidae } \\
\hline Uranoscopus scaber & 2 & 0.3 & 3.8 & 0.02 & $3-2$ & 2.5 & 0.1 \\
\hline \multicolumn{8}{|l|}{ Gobiidae } \\
\hline Gobiidae sp A & 2 & 0.3 & 3.8 & 0.02 & 3 & 3.0 & - \\
\hline Gobiidae sp B & 2 & 0.3 & 3.8 & 0.02 & 3 & 3.0 & - \\
\hline Callionymidae & & & 3.8 & & & & \\
\hline Callionymus lyra & 5 & 0.8 & 3.8 & 0.05 & $4-7$ & 5.6 & 0.2 \\
\hline Callionymidae spp. & 43 & 6.7 & 13.5 & 0.45 & - & - & - \\
\hline \multicolumn{8}{|l|}{ Carapidae } \\
\hline Carapus acus & 1 & 0.2 & 1.9 & 0.01 & 42 & 42.0 & - \\
\hline \multicolumn{8}{|l|}{ Triglidae } \\
\hline Eutrigla gurnardus & 1 & 0.2 & 1.9 & 0.01 & 3 & 3.0 & - \\
\hline Chelidonichthys lucerna & 1 & 0.2 & 1.9 & 0.01 & 11 & 11.0 & - \\
\hline \multicolumn{8}{|l|}{ Bothidae } \\
\hline Bothus podas & 1 & 0.2 & 1.9 & 0.01 & 18 & 18.0 & - \\
\hline Arnoglossus laterna & 10 & 1.6 & 1.9 & 0.10 & $3-5$ & 3.4 & 0.3 \\
\hline \multicolumn{8}{|l|}{ Lophiidae } \\
\hline Lophius piscatorius & 2 & 0.3 & 3.8 & 0.02 & $5-7$ & 6.0 & 0.1 \\
\hline
\end{tabular}

$N$ collected specimens, relative abundance on total catches, frequency index of positive hauls on the total samples $(f i=n \mathrm{i} / \mathrm{NT})$, mean abundance in the whole study area, mean $(X)$ and minimum-maximum range SL $(+\mathrm{SD})$

Diplodus sargus sargus, bothids Arnoglossus laterna and Bothus podas, paralepidids Lestidiops jayakari pseudosphyraenoides, Arctozenus risso and Paralepis. sp. followed numerically. The other 11 families were represented by one or very few specimens and accounted for $5.2 \%$ of total fish larvae.

\section{Horizontal distribution}

Species abundance decreased from group A (mean total abundance $17.81 \mathrm{ind} / 100 \mathrm{~m}^{3}$ ) to $\mathrm{B}$ (mean total abundance $2.64 \mathrm{ind} / 100 \mathrm{~m}^{3}$ ) and $\mathrm{C}$ (mean total abundance $2.73 \mathrm{ind} /$ $100 \mathrm{~m}^{3}$ ); it slightly increased to $\mathrm{D}$ at a bottom depth of $1,100 \mathrm{~m}$ (station 20) (mean total abundance 6.02 ind/ $100 \mathrm{~m}^{3}$ ). The inshore/coastal stations (A) were characterized by $67.3 \%$ of total taxa; the most collected species were the myctophid Benthosema glaciale and the clupeid Sprattus sprattus sprattus. In the shelf/slope stations (B) on a bathymetry ranging from 200 to $320 \mathrm{~m}$, species diversity
(36.5\% of total taxa) and abundance $\left(<1 \mathrm{ind} / 100 \mathrm{~m}^{3}\right)$ were lower; the most collected species were myctophids Lampanyctus pusillus and B. glaciale. In the offshore area (C) on a bottom depths of $620 \mathrm{~m}, 28.8 \%$ of total taxa were the myctophid Notoscopelus elongatus and stomiatid Stomias boa boa. In the pelagic area (D) on a bottom depth of 1,100 m, $48.1 \%$ of total taxa were Cyclothone spp., myctophid L. crocodilus, and other unidentified early stages of myctophids and clupeid Sardina pilchardus (Table 3). Symbolophorus veranyi, Phycis phycis, Gadus sp., Trachurus trachurus, Diplodus s. sargus, Gobiidae, Triglidae, Arnoglossus laterna and Lophius piscatorius were exclusively recorded in coastal stations, while Sardina pilchardus, Apodes sp., Gaidropsarus vulgaris and Merluccius merluccius occurred only in pelagic areas.

The horizontal distribution of larval fishes showed a patchy pattern. Although abundances at stations $<100 \mathrm{~m}$ were highest in the entire study area, there was a great difference between the maximum number of individuals 
Table 3 Horizontal distribution as mean abundance $\left(\mathrm{N} / 100 \mathrm{~m}^{3}\right)$ standardized for each group of stations and for station 6

\begin{tabular}{|c|c|c|c|c|}
\hline \multirow[t]{3}{*}{ Species/family } & A & $\mathrm{C}$ & $\mathrm{D}$ & \multirow[t]{3}{*}{6} \\
\hline & \multicolumn{3}{|c|}{ Bottom depth (m) } & \\
\hline & $>100$ & $\begin{array}{r}>200>600 \\
\left(\mathrm{~N} / 100 \mathrm{~m}^{3}\right)\end{array}$ & $>1,000$ & \\
\hline
\end{tabular}

\section{Clupeidae}

Sprattus sprattus sprattus

Sardina pilchardus

Clupeidae sp.

Gonostomatidae

$$
\begin{aligned}
& \text { Cyclothone braueri } \\
& \text { Cyclothone microdon } \\
& \text { Cyclothone spp. }
\end{aligned}
$$

Sternoptychidae

Argyropelecus hemigymnus

Photychthidae

Ichthyococcus ovatus

\begin{tabular}{|c|c|c|c|c|c|}
\hline Stomias boa boa & 0.23 & 0.13 & 0.42 & 0.18 & - \\
\hline \multicolumn{6}{|l|}{ Myctophidae } \\
\hline Benthosema glaciale & 5.56 & 0.36 & 0.12 & 0.18 & - \\
\hline Ceratoscopelus maderensis & - & - & - & 0.06 & - \\
\hline Hygophum benoiti & 0.11 & 0.2 & - & - & - \\
\hline Hygohum hygomii & 0.08 & 0.2 & - & 0.236 & - \\
\hline Lampanyctus crocodilus & 0.47 & 0.2 & 0.12 & 0.827 & - \\
\hline Lampanyctus pusillus & 0.19 & 0.4 & 0.06 & 0.177 & - \\
\hline Lobianchia dofleini & 0.08 & - & - & 0.059 & - \\
\hline Myctophum punctatum & 0.48 & 0.28 & 0.12 & 0.354 & - \\
\hline Notoscopelus bolini & 0.12 & 0.13 & 0.06 & 0.059 & - \\
\hline Notoscopelus elongatus & 0.6 & 0.11 & 0.79 & 0.177 & - \\
\hline Symbolophorus veranyi & 0.04 & - & - & - & - \\
\hline Myctophidae spp. & - & - & - & 0.77 & - \\
\hline \multicolumn{6}{|l|}{ Paralepididae } \\
\hline Lestidiops jayakari jayakari & - & 0.05 & 0.06 & 0.24 & - \\
\hline Arctozenus risso & - & 0.09 & 0.06 & 0.06 & - \\
\hline Paralepis sp. & - & - & - & - & - \\
\hline \multicolumn{6}{|l|}{ Congridae } \\
\hline Gnathophis mystax & - & - & 0.06 & - & 0.07 \\
\hline Apodes sp. & - & - & - & 0.06 & - \\
\hline \multicolumn{6}{|l|}{ Macroramphosidae } \\
\hline Macroramphosus scolopax & 0.08 & - & - & 0.06 & - \\
\hline \multicolumn{6}{|l|}{ Gadidae } \\
\hline Gaidropsarus biscayensis & 1.86 & 0.04 & 0.12 & - & - \\
\hline Gadiculus argenteus thori & 0.07 & - & - & - & - \\
\hline Gaidropsarus vulgaris & - & - & - & 0.06 & - \\
\hline Phycis phycis & 0.21 & - & - & - & - \\
\hline Gadus sp. & 0.11 & - & - & - & - \\
\hline Gadidae spp. & 0.47 & 0.09 & 0.24 & - & - \\
\hline
\end{tabular}

Vinciguerria poweriae

Stomiatidae

\begin{tabular}{|c|c|c|c|c|c|}
\hline \multirow[t]{3}{*}{ Species/family } & A & B & $\mathrm{C}$ & $\mathrm{D}$ & \multirow[t]{3}{*}{6} \\
\hline & \multicolumn{4}{|c|}{ Bottom depth (m) } & \\
\hline & $>100$ & $\begin{array}{r}>200 \\
(\mathrm{~N} / 10\end{array}$ & $\begin{array}{r}>600 \\
\left.00 \mathrm{~m}^{3}\right)\end{array}$ & $>1,000$ & \\
\hline \multicolumn{6}{|l|}{ Merluccidae } \\
\hline Merluccius merluccius & - & - & - & 0.06 & - \\
\hline \multicolumn{6}{|l|}{ Caproidae } \\
\hline Capros aper & 0.15 & - & - & 0.06 & - \\
\hline \multicolumn{6}{|l|}{ Carangidae } \\
\hline Trachurus picturatus & 0.48 & 0.04 & - & - & - \\
\hline Trachurus trachurus & 0.11 & - & - & - & - \\
\hline \multicolumn{6}{|l|}{ Sparidae } \\
\hline Boops boops & 0.14 & - & 0.3 & 0.12 & - \\
\hline Diplodus sargus sargus & 0.07 & - & - & - & - \\
\hline \multicolumn{6}{|l|}{ Ammodytidae } \\
\hline Gymnammodytes cicerellus & 0.46 & - & - & 0.24 & 0.07 \\
\hline \multicolumn{6}{|l|}{ Uranoscopidae } \\
\hline Uranoscopus scaber & 0.04 & - & 0.06 & - & - \\
\hline \multicolumn{6}{|l|}{ Gobiidae } \\
\hline Gobiidae sp A & 0.08 & - & - & - & - \\
\hline Gobiidae sp B & 0.08 & - & - & - & - \\
\hline \multicolumn{6}{|l|}{ Callionymidae } \\
\hline Callionymus lyra & 0.18 & - & - & - & - \\
\hline Callionymidae spp. & 1.57 & 0.05 & - & - & - \\
\hline \multicolumn{6}{|l|}{ Carapidae } \\
\hline Carapus acus & - & 0.05 & - & - & - \\
\hline \multicolumn{6}{|l|}{ Triglidae } \\
\hline Eutrigla gurnardus & 0.04 & - & - & - & - \\
\hline Chelidonichthys lucerna & 0.04 & - & - & - & - \\
\hline \multicolumn{6}{|l|}{ Bothidae } \\
\hline Bothus podas & - & 0.04 & - & - & - \\
\hline Arnoglossus laterna & 0.42 & - & - & - & - \\
\hline \multicolumn{6}{|l|}{ Lophiidae } \\
\hline Lophius piscatorius & 0.07 & - & - & - & - \\
\hline
\end{tabular}

Table 3 continued

(22.1 ind $/ 100 \mathrm{~m}^{3}$ ) and species (48\% on total taxa) occurring at station 3 , and the minimum $\left(0.4 \mathrm{ind} / 100 \mathrm{~m}^{3}\right.$ and $9.6 \%$, respectively), occurring above $630 \mathrm{~m}$ (station 6) (Fig. 5). Benthosema glaciale was the dominant species sampled in coastal stations, followed by Sprattus sprattus sprattus, Gaidropsarus biscayensis, Callionymidae spp. and Notoscopelus elongatus.

Both species diversity and abundance of fish larvae generally decreased along a neritic-shelf slope direction and slightly increased offshore. The study area was characterized by a typical shelf-dwelling ichthyoplankton assemblage constituted by early stages of fishes with very different habitats as adults and an offshore-dwelling ichthyoplankton 


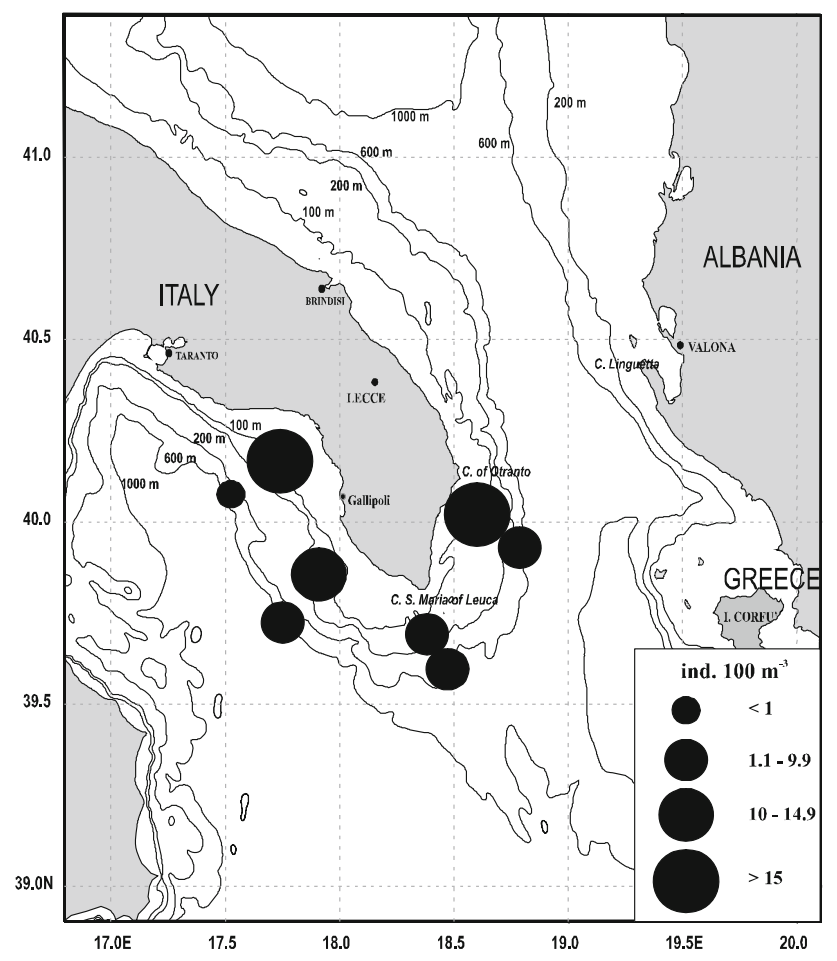

Fig. 5 Horizontal larval fish distribution with mean abundance values for all sampled station $\left(\mathrm{N} / 100 \mathrm{~m}^{3}\right)$

community, characterized mainly by meso- and bathypelagic species and a low number of juveniles.

Concerning the horizontal composition of the larval fish assemblages along the bathymetric gradient, the BrayCurtis similarity index (square-root transformed data) indicated a rather homogenous situation (SIMPER analysis: overall similarity $42 \%$, except station 6 ). The fish larval community of coastal waters (cluster A) was slightly more dissimilar (65\% on average) from the rest (Clusters B, C and $\mathrm{D})$, with the off-shore and pelagic assemblages characterized by an increasing dissimilarity with respect to the shelf/slope assemblage (53\% and 61\%, respectively). Similarity in inshore/coastal stations was mainly due to the species Benthosema glaciale (19\%), Callionymidae sp (11\%), Gaidropsarus biscayensis (10\%), S. s. sprattus (8\%), N. elongatus (6\%), Gadidae sp. (5\%), L. crocodilus (5\%), M. punctatum (5\%) and to species L. pusillus (14\%), L. crocodilus (10\%), B. glaciale (10\%), H. benoiti (10\%), H. hygomii (10\%), Gadidae sp. (8\%), M. punctatum (8\%), $N$. bolini (8\%) in shelf/slope stations (SIMPER analysis). The characterizing species $(50 \%$ of the assemblage) were N. elongatus (29\%), St. boa (16\%), B. boops (11\%) in offshore stations and Cycl sp. (24\%), L. crocodilus (16\%), M. punctatum (7\%) and S. pilchardus $(6 \%)$ in pelagic stations.

In order to study the co-occurrence of higher abundances of fish larvae with total zooplankton in the 8 sampling stations, the Pearson correlation coefficient was applied $(R=0.734, P<0.5)$. This statistical analysis was carried out taking into account the mean abundance value in any station and all sampling layers.

\section{Vertical distribution}

In terms of vertical distribution, abundance and species diversity values decreased from the surface to depth at all stations. Both inshore and offshore larval fish assemblages were present throughout the entire water column, but these were concentrated in layers of $20 \mathrm{~m}$. The 0 - to $40-\mathrm{m}$ layer was the richest with highest abundances occurring inshore (station 3) between 20 and $40 \mathrm{~m}\left(56.7 \mathrm{ind} / 100 \mathrm{~m}^{3}\right.$ ) (Fig. 3). Abundances generally decreased from $40 \mathrm{~m}$ to the maximum depth sampled except for station 31, where fish larvae peaked below the $60 \mathrm{~m}$ depth.

The Bray-Curtis similarity index, calculated on the basis of larval fish assemblage vertical composition (square-root transformed data), showed an early separation (5\% similarity) of the deeper samples (>100 m), which were characterized by an overall species richness of seven and the dominance of Cyclothone spp. In contrast, the shallower samples had a higher similarity level (40-60\%) as inferred by Benthosema glaciale (SIMPER analysis).

Species richness sharply decreased with depth (39 in the 0-40 layer, 24 and 16 in the 40-60 and 60-100 layers, respectively). This layer was characterized by a subsurface phytoplankton biomass maximum in March 2000 mainly due to the dominance of diatoms (V. Saggiomo, personal communication). Only in station 31, fish larvae peaked below the $60 \mathrm{~m}$ depth.

Regarding the co-occurrence of abundance peaks of fish larvae and total zooplankton along the water column, we found a Sorensen's index of $S=0.69$, which indicates the tendency of fish larvae to occur together rather independently with total zooplankton. For example, Fig. 6 shows the vertical distribution of total zooplankton density and copepod and fish larval abundances for stations 17 and 20, located along the same transect but on different bottom depths (100 and 1,000 m depth, respectively). Both showed the same vertical distribution profiles between total zooplankton and fish larvae, confirming their co-occurrence.

All larval fish species had preferential depths of maximum abundances. In the 0- to 40-m layer S. sprattus has its highest abundances; the 40- to 60-m stratum was characterized by $B$. glaciale; 60 - to 100 -m layer was populated by only a few late post-larvae; juveniles of bathypelagic or demersal species (15.4\%) inhabited layers below $100 \mathrm{~m}$ (Table 4).

\section{Dominant species}

A more detailed study was conducted on the three species that dominated the larval fish community. Benthosema 
Station 17

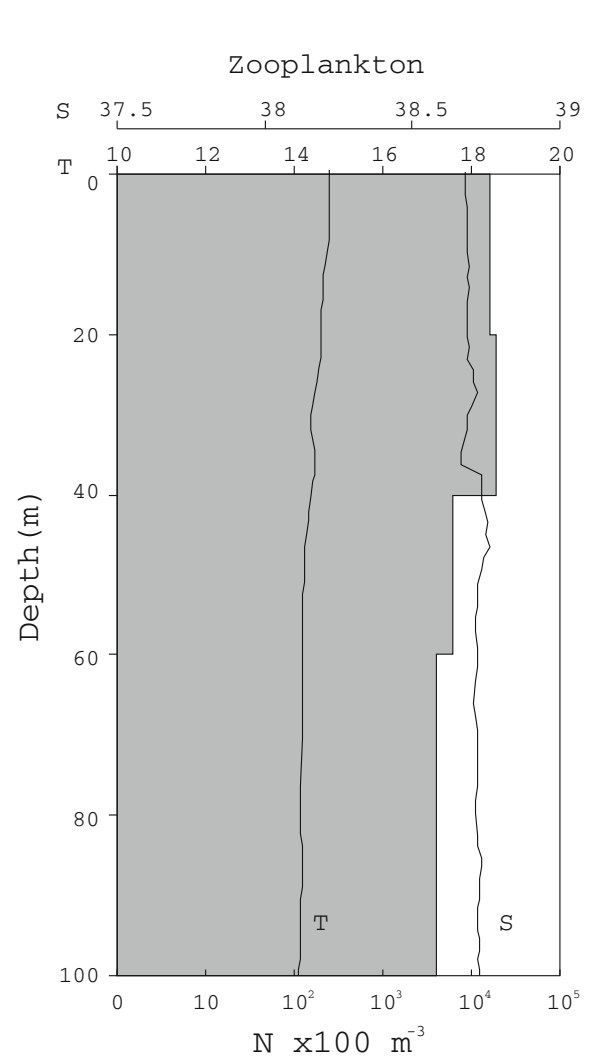

\section{Copepods}

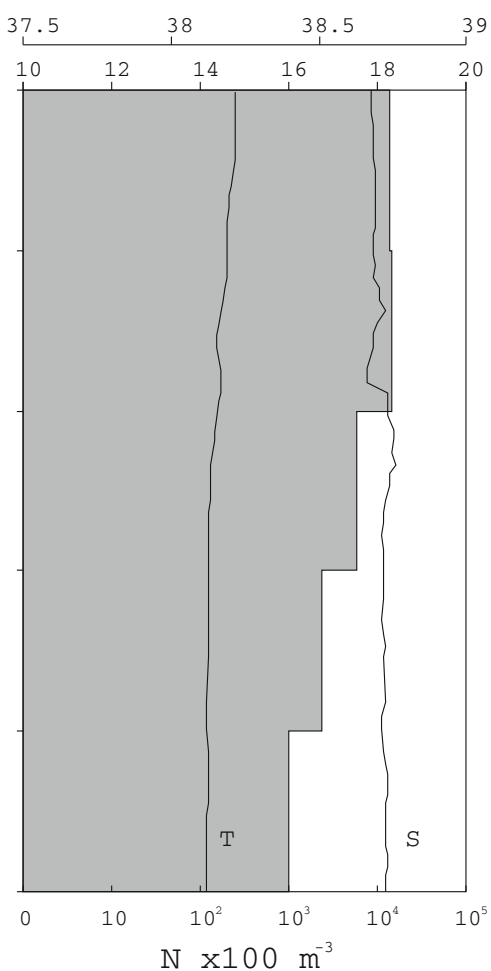

Station 20

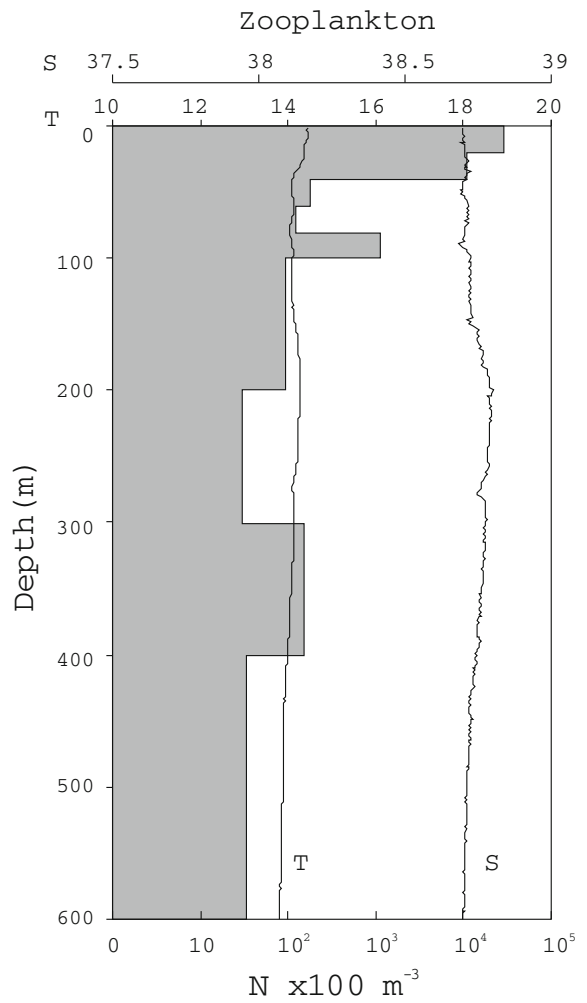

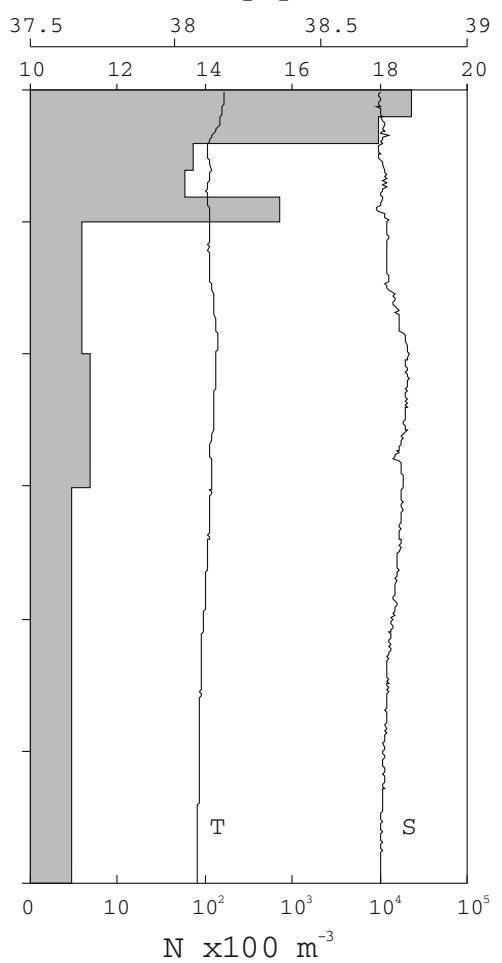

Copepods
Fish larvae
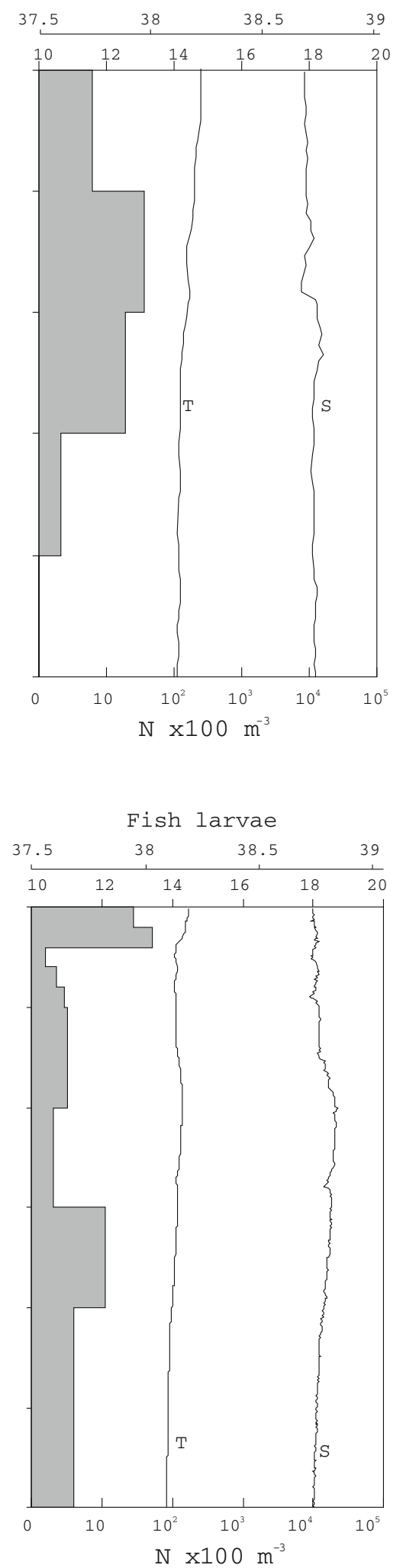

Fig. 6 Vertical distribution for total zooplankton density, copepod and fish larval abundance (grey bars) for stations 17 and 20 , located along the same transect on a 100- and 1,000-m depth bathymetry, respectively, and vertical temperature $\left({ }^{\circ} \mathrm{C}\right)$ and salinity (psu) profiles 
Table. 4 Vertical distribution and mean abundance $\left(\mathrm{N} / 100 \mathrm{~m}^{3}\right)$, of total fish larvae and for each species collected at different layer depth

\begin{tabular}{|c|c|c|c|c|c|}
\hline \multirow[t]{2}{*}{ Species/family } & \multicolumn{4}{|c|}{ Layer (m) } & \multirow{2}{*}{$\begin{array}{l}\text { Depth } \\
\text { range }(\mathrm{m}\end{array}$} \\
\hline & $0-40$ & $40-60$ & $\left(\mathrm{~N} / 100 \mathrm{~m}^{3}\right)^{60-100}$ & $100-600$ & \\
\hline Total ichthyoplankton & 14.03 & 10.15 & 1.73 & 1.02 & $0-600$ \\
\hline \multicolumn{6}{|l|}{ Clupeidae } \\
\hline Sprattus sprattus sprattus & 2.38 & 0.02 & 0.11 & - & $0-80$ \\
\hline Sardina pilchardus & 0.16 & - & - & - & $0-40$ \\
\hline Clupeidae spp. & 0.13 & 0.09 & - & - & - \\
\hline \multicolumn{6}{|l|}{ Gonostomatidae } \\
\hline Cyclothone braueri & 0.33 & - & - & - & $0-40$ \\
\hline Cyclothone microdon & 0.02 & 0.02 & - & - & $0-60$ \\
\hline Cyclothone spp. & - & 0.08 & - & 0.70 & $40-600$ \\
\hline \multicolumn{6}{|l|}{ Sternoptychidae } \\
\hline Argyropelecus hemigymnus & - & - & - & 0.07 & $200-300$ \\
\hline \multicolumn{6}{|l|}{ Photychtidae } \\
\hline Ichthyococcus ovatus & - & - & 0.12 & 0.10 & $60-400$ \\
\hline Vinciguerria poweriae & - & 0.12 & - & - & $40-60$ \\
\hline \multicolumn{6}{|l|}{ Stomiatidae } \\
\hline Stomias boa boa & 0.55 & - & 0.07 & - & $0-80$ \\
\hline \multicolumn{6}{|l|}{ Myctophidae } \\
\hline Benthosema glaciale & 1.63 & 6.22 & 0.35 & - & $0-100$ \\
\hline Ceratoscopelus maderensis & 0.03 & - & - & - & $0-20$ \\
\hline Hygophum benoiti & 0.13 & 0.04 & 0.07 & - & $0-100$ \\
\hline Hygohum hygomii & 0.21 & 0.02 & 0.12 & - & $0-80$ \\
\hline Lampanyctus crocodilus & 1.00 & 0.06 & - & - & $0-60$ \\
\hline Lampanyctus pusillus & 0.40 & 0.25 & 0.04 & - & $0-80$ \\
\hline Lobianchia dofleini & 0.06 & 0.07 & - & - & $0-60$ \\
\hline Myctophum punctatum & 0.43 & 0.66 & 0.19 & - & $0-80$ \\
\hline Notoscopelus bolini & 0.13 & 0.14 & 0.07 & - & $0-100$ \\
\hline Notoscopelus elongatus & 1.01 & 0.18 & - & - & $0-60$ \\
\hline Symbolophorus veranyi & - & - & 0.05 & - & $60-80$ \\
\hline Myctophidae spp. & 0.41 & - & - & - & \\
\hline \multicolumn{6}{|l|}{ Paralepididae } \\
\hline Lestidiops jayakari jayakari & 0.15 & 0.02 & - & - & $0-60$ \\
\hline Arctozenus risso & 0.06 & - & 0.07 & - & $0-100$ \\
\hline Paralepis sp. & - & - & - & 0.03 & $100-200$ \\
\hline \multicolumn{6}{|l|}{ Congridae } \\
\hline Gnathophis mystax & - & 0.12 & - & 0.03 & $40-200$ \\
\hline Apodes sp. & 0.03 & - & - & - & $40-20$ \\
\hline \multicolumn{6}{|l|}{ Macroramphosidae } \\
\hline Macroramphosus scolopax & 0.04 & 0.15 & - & - & $0-60$ \\
\hline \multicolumn{6}{|l|}{ Gadidae } \\
\hline Gaidropsarus biscayensis & 1.60 & 0.20 & - & - & $0-60$ \\
\hline Gadiculus argenteus thori & - & 0.14 & - & - & $40-60$ \\
\hline Gaidropsarus vulgaris & - & - & - & 0.03 & $100-200$ \\
\hline Phycis phycis & 0.10 & 0.13 & - & - & $20-60$ \\
\hline Gadus spp. & - & - & 0.11 & - & $80-60$ \\
\hline Gadidae spp. & 0.59 & 0.02 & - & - & $60-0$ \\
\hline
\end{tabular}


Table. 4 continued

\begin{tabular}{|c|c|c|c|c|c|}
\hline \multirow[t]{2}{*}{ Species/family } & \multicolumn{4}{|c|}{ Layer (m) } & \multirow{2}{*}{$\begin{array}{l}\text { Depth } \\
\text { range }(\mathrm{m}\end{array}$} \\
\hline & $0-40$ & $40-60$ & $\left(\mathrm{~N} / 100 \mathrm{~m}^{3}\right)^{60-100}$ & $100-600$ & \\
\hline \multicolumn{6}{|l|}{ Merluccidae } \\
\hline Merluccius merluccius & 0.03 & - & - & - & $20-40$ \\
\hline \multicolumn{6}{|l|}{ Caproidae } \\
\hline Capros aper & 0.13 & 0.07 & - & - & $0-60$ \\
\hline \multicolumn{6}{|l|}{ Carangidae } \\
\hline Trachurus picturatus & 0.44 & - & - & - & $0-40$ \\
\hline Trachurus trachurus & 0.09 & - & - & - & $20-40$ \\
\hline \multicolumn{6}{|l|}{ Sparidae } \\
\hline Boops boops & 0.35 & - & - & - & $0-40$ \\
\hline Diplodus sargus sargus & 0.06 & - & - & - & $0-40$ \\
\hline \multicolumn{6}{|l|}{ Ammodytidae } \\
\hline Gymnammodytes cicerellus & 0.58 & - & - & - & $0-40$ \\
\hline \multicolumn{6}{|l|}{ Uranoscopidae } \\
\hline Uranoscopus scaber & 0.06 & - & - & - & $0-20$ \\
\hline \multicolumn{6}{|l|}{ Gobiidae } \\
\hline Gobiidae sp A & 0.07 & - & - & - & $20-40$ \\
\hline Gobiidae sp B & 0.07 & - & - & - & $20-40$ \\
\hline \multicolumn{6}{|l|}{ Callionymidae } \\
\hline Callionymus lyra & - & - & 0.18 & - & $60-100$ \\
\hline Callionymidae spp. & 0.64 & 1.32 & 0.13 & - & $80-20$ \\
\hline \multicolumn{6}{|l|}{ Carapidae } \\
\hline Carapus acus & - & - & 0.04 & - & $80-100$ \\
\hline \multicolumn{6}{|l|}{ Triglidae } \\
\hline Eutrigla gurnardus & 0.04 & - & - & - & $20-40$ \\
\hline Chelidonichthys lucerna & 0.04 & - & - & - & $0-20$ \\
\hline \multicolumn{6}{|l|}{ Bothidae } \\
\hline Bothus podas & - & - & - & 0.06 & $100-200$ \\
\hline Arnoglossus laterna & 0.37 & - & - & - & $20-40$ \\
\hline \multicolumn{6}{|l|}{ Lophiidae } \\
\hline Lophius piscatorius & 0.03 & 0.08 & - & - & $20-60$ \\
\hline
\end{tabular}

glaciale (Reinhardt 1837). A total of 148 post-larvae and 3 metamorphosis stages of Benthosema glaciale were collected, representing about $41 \%$ of mesopelagic larval fishes. The species was present both inshore and offshore, with highest abundances occurring above the $110 \mathrm{~m}$ bottom depth (station 45: $9.8 \mathrm{ind} / 100 \mathrm{~m}^{3}$ ) and the minimum above the $320 \mathrm{~m}$ bottom depth (station 47: $0.1 \mathrm{ind} / 100 \mathrm{~m}^{3}$ ) (Fig. 7a). For the entire study area, the species always occurred below $20 \mathrm{~m} \mathrm{(Fig.} \mathrm{7b),} \mathrm{with} \mathrm{a} \mathrm{maximum} \mathrm{of}$ occurrence $\left(29.3 \mathrm{ind} / 100 \mathrm{~m}^{3}\right)$ in the $40-60 \mathrm{~m}$ at station 45 where temperature and salinity were less than $14^{\circ} \mathrm{C}$ and about 38.7, respectively. All developmental stages according to Moser and Ahlstrom (1970) until metamorphosis (at $12.7 \mathrm{~mm}$ ) occurred in the sampling period. Specimens of $5 \mathrm{~mm}$ were the most frequent, and some specimens had nearly metamorphosed (Fig. 7c). The vertical distribution of the mean sizes of $B$. glaciale was analyzed in Fig. 7d, which shows a general increase in size with depth.

Sprattus sprattus sprattus (Linneo 1758): A total of 59 post-larval and juvenile Sprattus sprattus sprattus (6-22 $\mathrm{mm}$ SL, mean $10.6 \mathrm{~mm} \pm 2.7$ ) were collected, constituting the second most abundant species captured. Its mean abundance $\left(\mathrm{N} / 100 \mathrm{~m}^{3}\right)$ showed decreasing values from the coast to the open sea. It was collected at six stations (Fig. 8a) and occurred in greatest numbers at station 3 where the highest mean relative abundance was recorded $\left(6.43 \mathrm{ind} / 100 \mathrm{~m}^{3}\right)$. Highest abundances occurred between 0 and $20 \mathrm{~m}\left(19.2 \mathrm{ind} / 100 \mathrm{~m}^{3}\right)$ at station 3 where temperature and salinity were around $14^{\circ} \mathrm{C}$ and over 38.7 , 

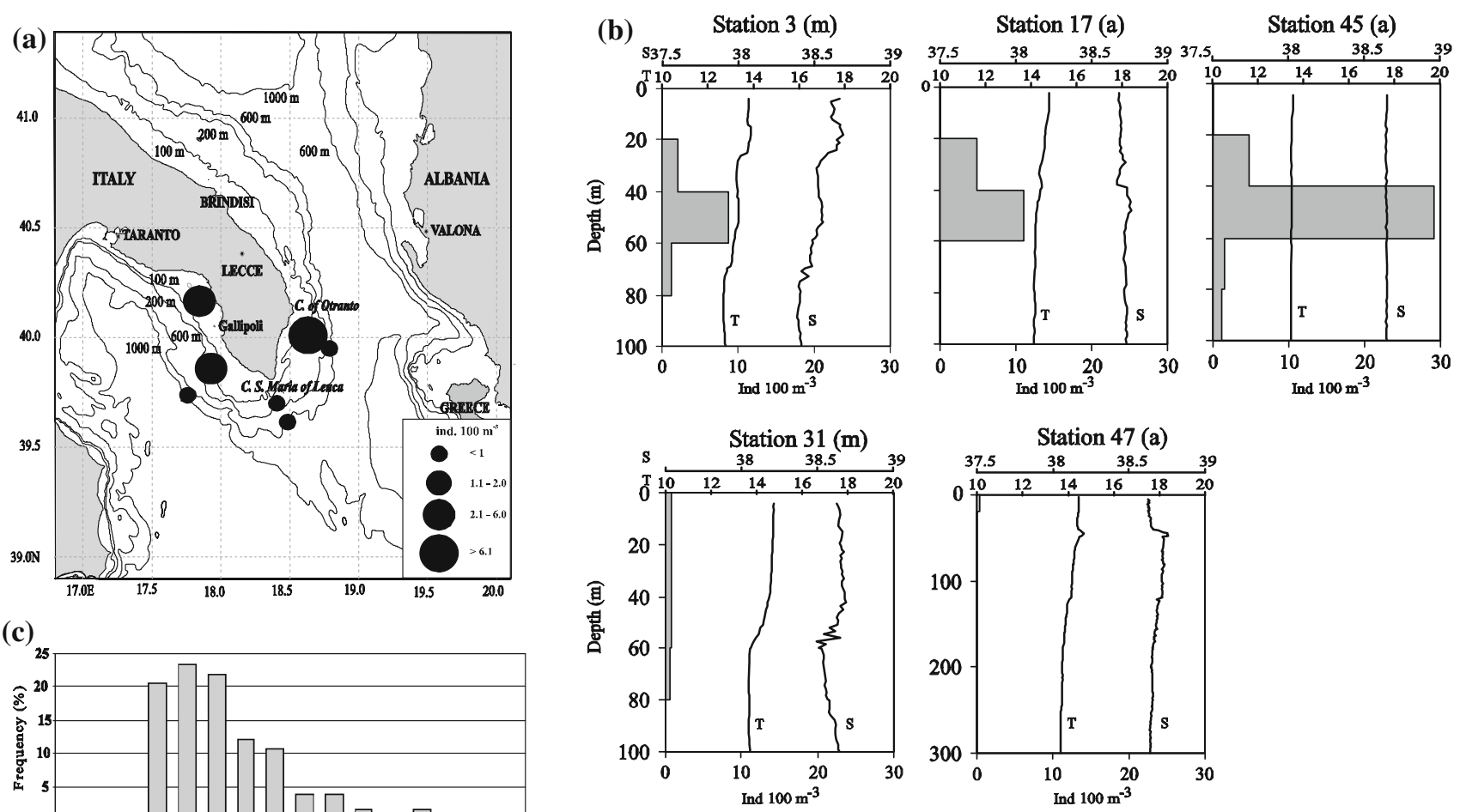

(c)
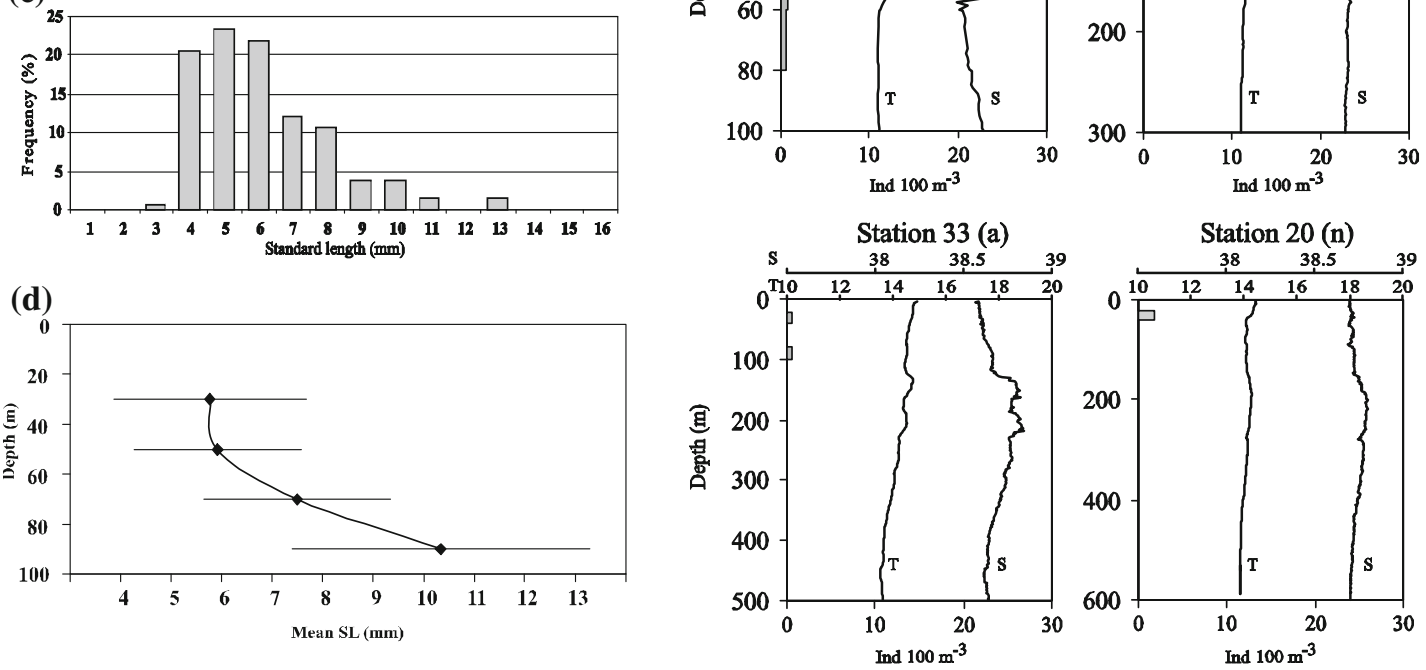

Fig. 7 Study on post-larval Benthosema glaciale: a horizontal distribution and abundance $\left(\mathrm{N} / 100 \mathrm{~m}^{3}\right)$ in the 0 - to $100-\mathrm{m}$ layer; b vertical distribution (grey bars) with temperature and salinity

respectively (Fig. 8b); S. $s$ sprattus was only absent in surface layers at the offshore station 47 where it occurred between 60 and $80 \mathrm{~m}$. The length-frequency distribution of S. $s$ sprattus followed a bimodal trend because the population was constituted by specimens probably born during two different periods (Fig. 8c).

Notoscopelus elongatus (Costa, 1844): A total of 33 post-larval and nearly juvenile Notoscopelus elongatus (3-16 $\mathrm{mm} \mathrm{SL}$, mean $5.4 \mathrm{~mm} \pm 1.5$ ) were captured, constituting the third species collected in terms of abundance. Mean abundances were almost similar throughout the study area (between 0.2 and $1.1 \mathrm{ind} / 100 \mathrm{~m}^{3}$ ). Highest horizontal abundances were recorded at station $3\left(1.1 / 100 \mathrm{~m}^{3}\right)$ (Fig. 9a). N. elongatus occurred only in the $0-$ to $60-\mathrm{m}$ layer, with a maximum in the 20- to 40-m layer at station 17 (Fig. 9b) where temperature and salinity were about profiles ( $m$ morning, $a$ afternoon, $n$ night); c length-frequency distribution of standard length; d mean SL distribution along the water column (mean, \pm standard deviation)

$14^{\circ} \mathrm{C}$ and 38.7 , respectively. The length-frequency distribution of $N$. elongatus indicated that the $4 \mathrm{~mm}$ SL size was the most representative, even if one larger specimen $16 \mathrm{~mm}$ SL was collected (Fig. 9c).

\section{Discussion}

The study site is located in a region where the relatively eutrophic waters from the Adriatic Sea mix with the oligotrophic waters of the Ionia Sea. In this area, the passage of weak surface fronts which can affect the local biology is often observed (Budillon et al. 2010). Over the winterspring period, variability of the surface phytoplankton bloom in the southern Adriatic Sea is essentially controlled by local winter climatic conditions (i.e., maximum 

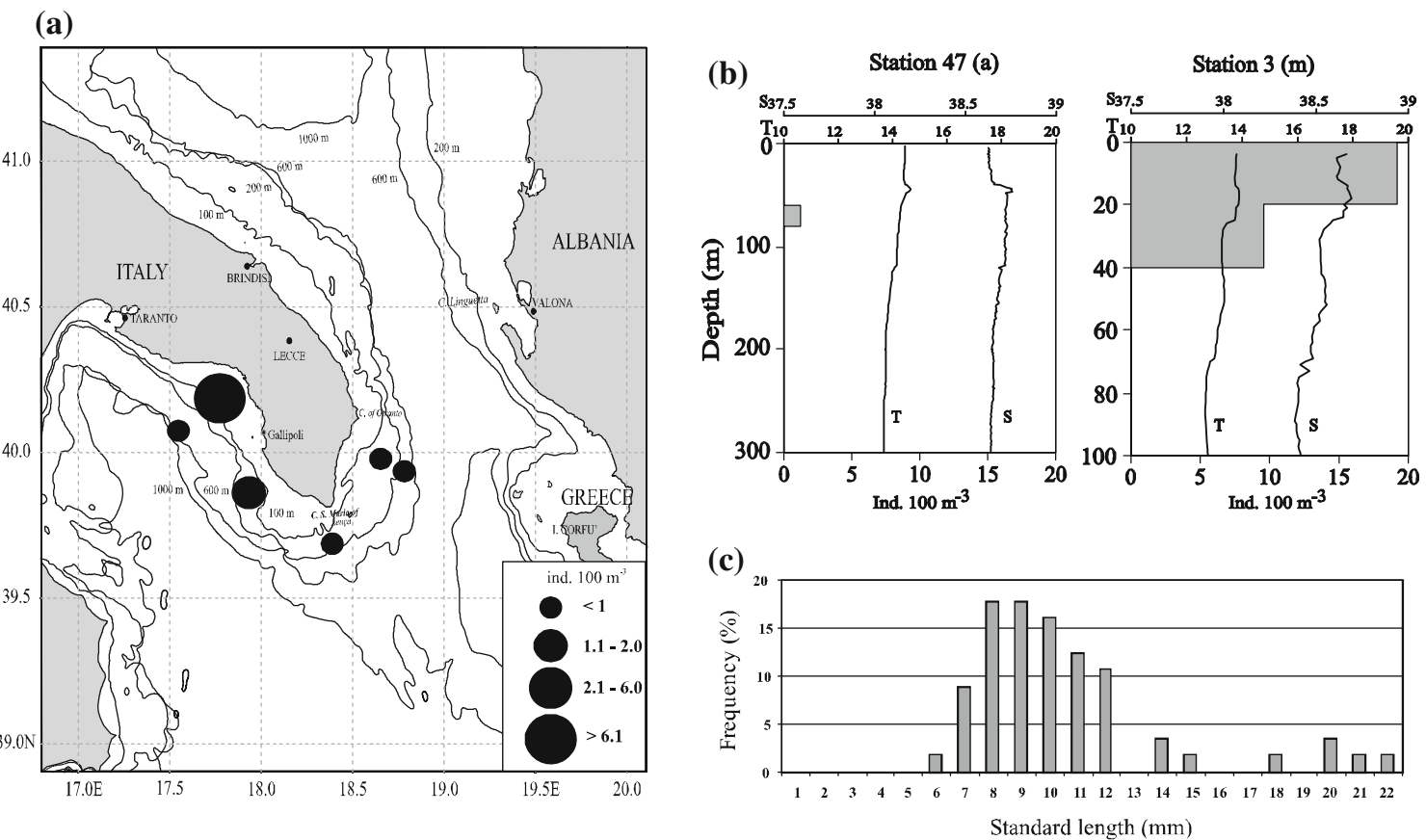

Fig. 8 Study on Sprattus sprattus: a horizontal distribution and abundance (N/100 $\left.\mathrm{m}^{3}\right)$ in the 0- 100-m layer; b vertical distribution (grey bars) with temperature and salinity profiles ( $m$ morning, $a$ afternoon); $\mathbf{c}$ length-frequency distribution of standard length
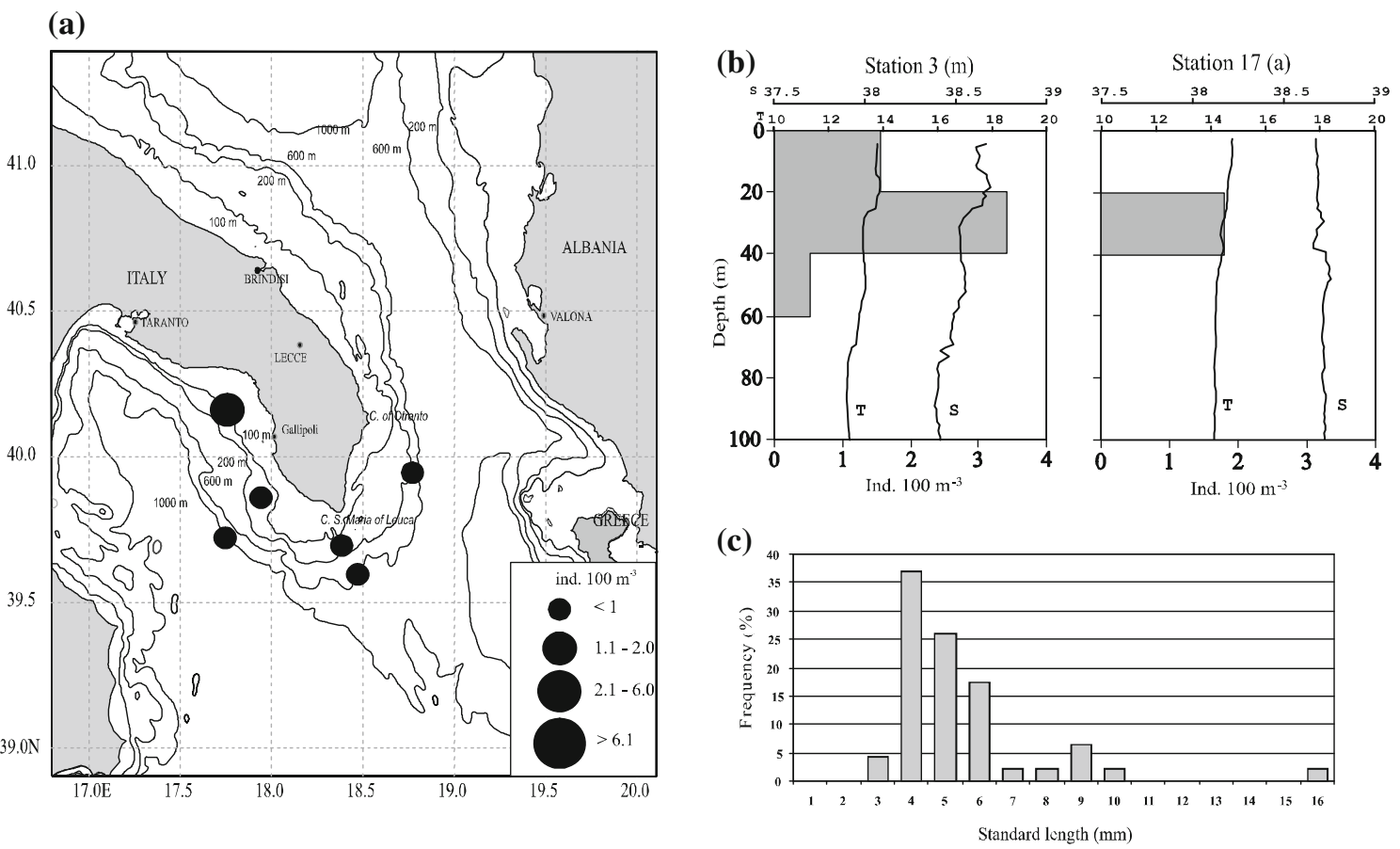

Fig. 9 Study on Notoscopelus elongatus: a horizontal distribution and abundance (N/100 $\left.\mathrm{m}^{3}\right)$ in the 0- to 100-m layer; $\mathbf{b}$ vertical distribution (grey bars) along temperature and salinity profiles ( $m$ morning, $a$ afternoon); c length-frequency distribution of standard length

convective depth). Since surface blooms were less intense in spring 2000 (in April chlorophyll concentrations never exceeded $0.5 \mathrm{mg} / \mathrm{m}^{3}$, Santoleri et al. 2003), because of deeper convection and increased frequency of strong wind bursts that disrupted stratification, the presence of richer
Adriatic waters along the Apulian coast was less intense. This condition was observed during the same sampling period by Sabetta et al. (2004) who reported a phytoplankton biomass mean density of $0.34 \pm 0.13 \mathrm{mg} / \mathrm{m}^{3}$ as Chla. 
This scenario is consistent with our results: during the sampling period, a clear dominance of ISW was noted over the entire study region in the euphotic layer associated with a general homothermy typical of a late-winter mixed water column with no evidence of the presence of waters of Adriatic origin (ASW).

We found no correlation between larval fish assemblages and vertical temperature profiles. During the period of sampling, the water column was generally well mixed until the maximum sampled depth $(600 \mathrm{~m})$. Horizontal and vertical mixing favoured zooplankton aggregation (Le Fèvre 1986) available as food for adult fish species (Gorelova 1983; Dalpadado and Gjøsaeter 1988. The sampling period is when many spring coastal spawning fish reach maximum abundances. Their larvae feed on abundant plankton in the spring bloom, and they grow rapidly throughout the early summer (Sabatés 1990; Koutrakis et al. 2004). In fact, in our samples there was a correlation in terms of abundance between total zooplankton and larval fish richness values. The Pearson linear correlation coefficient showed a high correlation in terms of spatial distribution abundance values between total zooplankton and larval fish assemblages. Regarding the vertical distribution of fish larvae, Sorensen's index showed that larval fish abundance peaks co-occurred with total zooplankton abundance along the water column. Highest densities for all larval fish species occurred in the 0- to 60-m layer, decreasing with depth. A similar trend was also seen for the entire zooplankton community. This may be due to the feeding behaviour of fish larvae that fed on the smaller mesozooplankton species. In this respect, Sabatés et al. (2003) described a clear relationship between light intensity and the feeding behaviour of $B$. glaciale and $M$. punctatum larvae, representing the small herbivorous zooplankton species food for some larval fish species. In fact it is well known that layers with higher light intensity promoted higher primary production.

Generally, in temperate coastal regions, the ichthyoplankton is comprised of demersal and pelagic fishes whose reproductive cycles are usually highly seasonal (Richardson et al. 1980). In this study, a total of 46 early stages of teleosts, belonging to 38 genera and 22 families, corresponding to $20.4 \%$ of the 225 adult species of teleosts reported by Pastore (1976) and Parenzan (1983), were collected in the northern Ionian Sea off the south-eastern Italian coasts. The taxonomic larval fish composition identified in this study is typical of coastal and continental shelf regimes, confirming the findings of Palomera and Olivar (1996), who found that these oceanic taxa appeared year-round but showed their maximum abundances in spring due to seasonality of reproduction and physical oceanographic events.

Coastal areas are generally favourable environments for ontogenesis of early stages of fishes. Overall, early spring is a crucial moment for the reproductive success of fishes (Bruno et al. 2001). In fact, the high density of species recorded in our samples can probably be linked to the spreading of floating eggs synchronized with primary production, cycles of zooplankton and their specific composition (Vucetic 1975; Casavola et al. 1998; Bruno et al. 2001).

The horizontal distribution observed in our samples is in accordance with Sabatés (1990) who found clear inshore/ offshore distribution gradients for fish larvae in another area. Larvae of pelagic neritic species were distributed uniformly with distance from the coast; larvae of offshore mesopelagic fishes had no clear pattern but were frequently abundant near shore. The decline in both number of species and abundance is also true for adult fish specimens in Mediterranean areas (D'onghia et al. 1998, 2002; Kallianiotis et al. 2000). The high occurrence of larvae of mesopelagic species in coastal areas has been reported before on the Catalan coast (Sabatés and Masò 1990; Olivar and Palomera 1994) as well in other regions (John 1984; Olivar and Beckley 1994) and has been associated with intrusions of oceanic waters into the coast.

In terms of vertical distribution, the abundance and species diversity decreased from the surface to depth, with each larval fish species showing a peculiar vertical stratification pattern. The distribution of some species changed with size and developmental stage; in some species, all stages of larval development to metamorphosis were found within larval depth ranges; in others, late developmental stages were clearly absent from the ichthyoplankton (Loeb 1979). Probably because of homogeneous temperature and salinity values, both inshore and offshore larval fish assemblages inhabited the entire water column until $600 \mathrm{~m}$, although only few late post-larvae and juveniles of bathypelagic or demersal species inhabited layers below the $100 \mathrm{~m}$ depth. Probably due to food availability, most of the assemblage was confined to the upper $100 \mathrm{~m}$ and in particular in the 20- to 40-m-depth interval where the maximum abundance occurred both inshore and offshore. These data agree with Loeb (1979), who found that within the upper $100 \mathrm{~m}$, a significant relationship exists between larval abundance and macrozooplankton biomass. In fact, in the upper $25 \mathrm{~m}$ an inverse relationship was found, and below this depth larval abundance was positively correlated with zooplankton biomass.

Distribution of larval stages of shelf-dwelling species are generally strongly associated with the adult habitat (Palomera and Rubiés 1979; Sabatés 1990), while larvae of oceanic species show maximum concentrations offshore, although they may also occur in areas where bottom depths are too shallow for adults, i.e., over continental shelf (Sabatés and Masò 1990; Olivar and Palomera 1994). In our study, coastal epipelagic fishes were represented 
mainly by Sprattus sprattus sprattus, which was the most abundant species in the nearshore site due to its spawning in coastal areas, compared to the other clupeid species Sardina pilchardus, which is more common in the Mediterranean. This latter species spawns at higher temperatures $\left(11-15^{\circ} \mathrm{C}\right)$ and generally prefers highly saline waters. In general, the larvae of mesopelagic fish showed deeper distributions in the water column than the shelf-dwelling species, which had already been indicated from other geographical areas (Röpke 1993; Sabates 2004). The larvae of Argyropelecus hemigymnus showed deep distributions, as reported by Olivar et al. (1998) during the stratified summer period of the Mediterranean.

Among the Myctophidae, the larvae of the subfamily Lampanyctinae showed a shallower vertical distribution than that of larvae of the Myctophinae subfamily (Sabates 2004). For example, the larvae of Notoscopelus elongatus showed a more surface-oriented distribution, whereas the larvae of Myctophum punctatum, belonging to the Myctophinae subfamily, showed a deeper distribution until $100 \mathrm{~m}$. Also, the most abundant species identified, Benthosema glaciale, belonging to the Myctophinae subfamily, showed a deeper distribution. Röpke (1993) indicated a similar distribution trend, even if in another area as the Arabian sea. An exclusively deep occurrence was shown by larvae of Argyropelecus hemigymnus, as indicated by Olivar et al. (1998) during the summer stratified period in the Mediterranean.

The similar trend showed in vertical distribution of fish larvae at all sampled stations can be justified by the absence of a thermocline and strong salinity gradients that promote vertical movements of larvae between layers. It is in fact well known that the preference for a certain depth range can be related to various environmental, physical and biological parameters, which ensure optimum survival for larval fish (Sabates 2004). Given the homogeneity of the physical characteristics throughout the water column, and given that all the sampling collections were carried out during the daytime, except station 20 that was sampled in the afternoon, the fish larvae were situated near the surface where they found higher concentrations of food. Röpke (1993) concluded that prey densities seem to be more critical in the vertical distribution of fish larvae than physical gradients.

In conclusion, this study has shown that all larval fish species have similar patterns in terms of vertical distribution along the water column at the sampled stations, both inshore and offshore, with maximum densities occurring until the $100 \mathrm{~m}$ depth. We show that most species inhabit the surface layers due to their feeding behaviour, as confirmed by the cooccurrence indices applied to fish larvae and total zooplankton abundances. As already noted by Sabates (2004), high light levels lead to high primary production and therefore high concentrations of prey available for the herbivorous trophic levels of the food chain.
Acknowledgments We thank the National Inter-University Consortium for Marine Sciences (CoNISMa), of the Ministry of Education, University and Research (MIUR) for the coordination of the INTERREG 1999-2001 Italia-Grecia project. Thanks go to Dr Adianna Ianora of the Zoological Station of Naples for the English revision of the manuscript.

\section{References}

Acevedo S, Fives JM (2001) The distribution and abundance of the larval stages of the Myctophid Benthosema glaciale (Reinhardt) in the Celtic Sea and west coast of Ireland in 1998. Biol and Environ Proc Royal Irish Academy 101B(3):245-249

Bignami F, Salusti E, Schiarini S (1990) Observations on a bottom vein of dense water in the Southern Adriatic and Ionian Seas. J Geophys Res 95(C5):7249-7259

Bruno R, Granata A, Cefali A, Guglielmo L, Brancato G, Barbera P (2001) Relationship between fish larvae biomass and plankton production in the south Tyrrhenian Sea. In: Faranda FM, Gugliemo L, Spezie G (eds) Mediterranean ecosystems structures and processes. Springer, Milano, pp 143-148

Budillon G, Lo Bue N, Siena G, Spezie G (2010) Hydrographic characteristics of water masses and circulation in the Northern Ionian Sea. Deep Sea Res Part II 57(5-6):441-457

Casavola N, Hajderi E, Marano G (1998) Relationship between the density of Engraulis encrasicholus eggs and zooplanktonic biomass in the Southern Adriatic Sea. Biol Mar Medit 5:56-62

Clark KR, Gorley RN (2001) PRIMER v5: user manual/tutorial. PRIMER-E, Plymouth

Cuttitta A, Arigo A, Basilone G, Bonanno A, Buscaino G, Rollandi L, Garcia Lafuente J, Garcia A, Mazzola S, Patti B (2004) Mesopelagic Fish Larvae Species in the Strait of Sicily and their Relationships to Main Oceanographic Events. Hydrobiol 527:177-182

D’Onghia G, Tursi A, Maiorano P, Matarrese A, Panza M (1998) Demersal fish assemblages from the bathyal grounds of the Ionian Sea (middle-eastern Mediterranean). Ital J Zool 65(Suppl):287-292

D’Onghia G, Politou CY, Mastrototaro F, Mytilineou CH, Matarrese A (2002) Biodiversity from the upper slope demersal community of the eastern Mediterranean: preliminary comparison between two areas with and without fishing impact. J Northw Atl Fish Sci Vol 31:1-11

D’Onghia G, Mastrototaro F, Matarrese A, Politou CY, Mytilineou CH (2003) Biodiversity of the upper slope demersal community in the eastern Mediterranean: preliminary comparison between two areas with and without trawl fishing. J Northw Atl Fish Sci $31: 263-273$

D’Onghia G, Loris D, Politou Cy, Sion L, Dokos J (2004a) New records of deep-water teleost fishes in the Balearic Sea and Ionian Sea (Mediterranean Sea). Sci Mar 68(Suppl. 3):171-183

D’Onghia G, Politou CY, Bozzano A, Lloris D, Rotllant G, Sion L, Mastrototaro F (2004b) Deep-water fish assemblages in the Mediterranean Sea. Sci Mar 68(Suppl. 3):87-99

Dajoz R (1971) Précis d'Écologie, 2nd edn. Edit Dunod, Paris, p 434

Dalpadado P, Gjøsaeter J (1988) Feeding ecology of the lanternfish Benthosema pterotum from the Indian Ocean. Mar Biol 99:555-567

Gacic M, Kovacevic V, Manca B, Papageorgiou E, Poulain PM, Scarazzato P, Vetrano A (1996) Thermohaline properties and circulation in the Strait of Otranto. In: Briand F (ed) Dynamics of Mediterranean straits and channels, Bull Inst Oceanogr Spec Iss 17, CIESM Sci Series 2:117-145

Gacic M, Civitarese G, Ursella L (1999) Spatial and seasonal variability of water and biogeochemical fluxes in the Adriatic Sea. In: Malanotte-Rizzoli P, Eremeev VN (eds) The Eastern 
Mediterranean as a laboratory basin for the assessment of contrasting ecosystems. Kluwer Academic Publisher, Dordrecht, pp 335-357

Giordani P, Helder W, Koning E, Miserocchi S, Danovaro R (2002) Gradients of benthic-pelagic coupling and carbon budgets in the Adriatic and Northern Ionian Sea. J Mar Syst 33-34:365-387

Giovanardi O, Romanelli M, Fanelli G (1989) Distribuzione ed abbondanza degli stadi planctonici di pesci, in particolare Cupleiformi, nelle acque del Mar Jonio. Nova Thalass 10:187-194

Gjøsaeter J, Kawaguchi K (1980) A review of the world resources of mesopelagic fish. FAO Fish tech Pap 193:1-151

Gorelova TA (1983) A quantitative assessment of consumption of zooplankton by epipelagic lanternfishes (Family Myctophidae) in the equatorial Pacific Ocean. J Ichthyol 23:106-113

Hureau JC, Monod T (1978) Check-list of the fishes of the northeastern Atlantic and the Mediterranean (CLOFNAM), vol 1-2. UNESCO, Paris

John HC (1984) Horizontal, vertical distribution of lancelet larvae, fish larvae in the Sargasso Sea during spring 1979. Meeresforsch 31(2): 133-143

Kallianiotis A, Sofronidis K, Vidoris P, Tselepidis A (2000) Demersal fish and megaphaunal assemblages on the Cretan continental shelf and slope (NE Mediterranean): seasonal variation in species density, biomass and diversity. Prog Oceanogr 46:429-455

Koutrakis ET, Kallianiotis AA, Tsikiliras AC (2004) Temporal pattern of larval fish distribution and abundance in a coastal area of northern Greece. Sci Mar 68:585-595

Le Fèvre J (1986) Aspects of the biology of frontal systems. Adv Mar Biol 23:163-299

Legendre P, Legendre L (1998) Numerical ecology. Elsevier, Amsterdam

Loeb VJ (1979) Larval fishes in the zooplankton community of the North Pacific central gyre. Mar Biol 53:173-191

Manca BB, Scarazzato P (2001) The two regimes of the intermediate/ deep circulation in the Ionian-Adriatic Seas. Arch Oceanogr Limnol 22:15-26

Matarrese A, D’Onghia G, Tursi A, Basanisi M (1996) New information on the ichthyofauna of the South-Eastern Italian coasts (Ionian Sea). Cybium 20(2):197-211

McGowen GE (1993) Coastal ichthyoplankton assemblages, with emphasis on the Southern California Bight. Bull Mar Sci 53:692-722

Mytilineou C, Politou C, Papaconstantinou C, Kavadas S, D’Onghia G, Sion L (2005) Deep-water fish fauna in the Eastern Ionian Sea. Belg J Zool 135(2):229-233

Olivar MP, Beckley LE (1994) Influence of the Agulhas current on the distribution of lanternfish larvae off the southeast coast of Africa. J Plankton Res 16(12):1759-1780

Olivar MP, Palomera I (1994) Ontogeny and distribution of Hygophum benoiti (Pisces Myctophidae) of the western Mediterranean. J Plankton Res 16(8):977-991

Olivar MP, Sabates A, Abello P, Garcia M (1998) Transitory hydrographic structures and distribution of fish larvae and neustonic crustaceans in the north-western Mediterranean. Oceanol Acta 21:95-104

Palomera I, Olivar P (1996) Nearshore ichthyoplankton off the Costa Brava (NW Mediterranean). Publ Espec Inst Esp Oceanogr 22:71-75

Palomera I, Rubiés P (1979) Ichthyoplancton de la Mer Catalane. Larves de poissons récoltées sur deux stations fixé devant Barcelone au cours d'un cycle annuel (1975-1976). Rapp Comm Int Mer Medi 25/26(10):201-206

Palomera I, Olivar MP, Morales-Nin B (2005) Larval development and growth of the European hake Merluccius merluccius in the northwestern Mediterranean. Sci Mar 69:251-258
Parenzan P (1983) Puglia Marittima. Congedo vols I-II

Pastore M (1976) Note ittiologiche del Golfo di Taranto. I generalità e lista delle specie. Oebalia 2:91-103

Potoschi A, Cavallaio G, Sturiale P, Lo Duca G (1994) Uova e larve di pescespada (Xiphias gladius L. 1758), tonno (Thunnus thynnus L. 1758) ed alalunga (Thunnus alalunga Bonn.1788) pescate nello Jonio della Sicilia Orientale. Biol Mar Medit 1:119-124

Richardson SL, Laroche JL, Richardson MD (1980) Larval fish assemblages and associations in the north-east Pacific coast along the Oregon coast, winter-spring 1972-1975. Estuar Coast Mar Sci 11:671-699

Röpke A (1993) Do larvae of mesopelagic fishes in the Arabian Sea adjust their vertical distribution to physical and biological gradients? Mar Ecol Progr Ser 101:223-235

Sabates A (2004) Diel vertical distribution of fish larvae during the winter-mixing period in the Northwestern Mediterranean. J Mar Sc 61:1243-1252

Sabatés A (1990) Distribution pattern of larval fish populations in the Northwestern Mediterranean. Mar Ecol Prog Ser 59:75-82

Sabatés A, Masò M (1990) Effect of a shelf slope front on the spatial distribution of mesopelagic fish larvae in the western Mediterranean. Deep Sea Res 37:1085-1098

Sabatés A, Masò M (1992) Unusual larval fish distribution pattern in a coastal zone of the western Mediterranean. Limnol Ocenogr $37: 1252-1260$

Sabates A, Salat J, Masò M (2004) Spatial heterogeneity of fish larvae across a meandering current in the northwestern Mediterranean. Deep Sea Res Part I 51:545-557

Sabatés A, Bozzano A, Vallvey I (2003) Feeding pattern and the visual light environment in myctophid fish larvae. J Fish Biol 63:1476-1490

Sabetta L, Fiocca A, Margheriti L, Vignes F, Basset A, Mangoni O, Carrada GC, Ruggieri N, Ianni C (2004) Phytoplankton size structure and environmental forcing within the euphotic zone in the Southern Adriatic-Ionian coastal area. Chem and Ecol 20:303-317

Sameoto DD, Jaroszyski LO, Fraser WB (1980) BIONESS, a new design in multiple net zooplankton samplers. Can J Fish Aquat Sci 37:722-724

Santoleri R, Banzon V, Marullo S, Napolitano E, D’Ortenzio F, Evans $\mathrm{R}$ (2003) Year-to-year variability of the phytoplankton bloom in the southern Adriatic Sea (1998-2000): sea-viewing Wide Fieldof-view Sensor observations and modeling study. J Geophys Res 108(C9):8122. doi:10.1029/2002JC001636

Somarakis S, Maraveya E, Tsimenides N (2000) Multispecies Ichthyoplankton associations in epipelagic species: is there any intrinsic adaptive function? Belg J Zool 130:125-129

Somarakis S, Ganias K, Siapatis A, Koutsikopoulos C, Machias A, Papaconstantinou C (2006) Spawning habitat and daily egg production of sardine (Sardina pilchardus) in the eastern Mediterranean. Fish Ocean 15:281-292

Sorensen $\mathrm{T}$ (1948) A method of establishing groups of equal amplitude in plant society based on similarity of species content. K. Danske Vidensk Selsk 5:1-34

Stergiou KI, Karpouzi VS (2002) Feeding habits and trophic levels of Mediterranean fish. Rev Fish Biol Fish 11:217-254

Tranter DJ (1962) Zooplankton abundance in Australasian waters. Aust J Mar Freshw Res 13:106-142

Vucetic T (1975) Synchronism of the spawning season of some pelagic fishes (sardine, anchovy) and the timing of the maximal food (zooplankton) production in the central Adriatic. Staz Zool Napoli 39 Suppl:347-365

Whitehead PJP, Bauchot ML, Hureau JC, Nielsen J, Totonese E (1984-1986) Fishes of the North-eastern Atlantic and the Mediterranean, vols 1-3. UNESCO, Paris, p 1473 